\title{
Numerical experiments on interactions between wave motion and variable-density coastal aquifers
}

R. Bakhtyar*, D.A. Barry, A. Brovelli

Laboratoire de technologie écologique, Institut d'ingénierie de l'environnement, Faculté de l'environnement naturel, architectural et construit (ENAC), Station 2, Ecole polytechnique fédérale de Lausanne (EPFL), 1015 Lausanne, Switzerland. Emails: roham.bakhtyar@epfl.ch, andrew.barry@epfl.ch, alessandro.brovelli@epfl.ch

Accepted for publication 1 September 2011

* Author to whom all correspondence should be addressed. Ph. +41 (21) 693-8087, Fax. +41 (21) 693-8035 
ABSTRACT: A comprehensive two-dimensional (cross-shore) process-based numerical model of nearshore hydrodynamics (based on the Navier-Stokes equations, $k$ - $\varepsilon$ turbulence closure and the Volume-Of-Fluid method), beach morphology, and variable-density groundwater flow (SEAWAT-2000) was developed. This model, which was applied at the field scale, relaxes simplifications in existing models that do not include such detailed mechanistic descriptions. Numerical experiments were conducted to investigate the effects of varying aquifer, beach and wave characteristics (e.g., inland groundwater head, sand grain size, different wave heights and periods) on the coupled system. Spilling and plunging breakers on dissipative and intermediate beaches were simulated. For a given set of boundary conditions, the model was run for $1 \mathrm{y}$ without the hydrodynamic sub-model to achieve a realistic salt-/freshwater interface. Then, the hydrodynamic component was run for $15 \mathrm{~min}$ and the model results analyzed. The main features considered were groundwater circulation, saltwater wedge position, in/exfiltration across the beach face, and beach morphology. The predictions of the numerical model agree well with existing understanding and experimental measurements. For an inland watertable that is lower than the still water level (SWL), such that the groundwater flow is mainly landward, on both coarse and fine sand beaches the addition of wave motion moves the saltwater wedge further landward. For an inland watertable that is higher than the SWL, the opposite behavior occurred. The numerical experiments showed that more sediment transport takes place on intermediate beaches than on dissipative beaches. In addition, beach profile variations are greater under plunging breakers, while coarse sand beaches are steeper than fine sand beaches for the same wave conditions. There is a strong correlation between in/exfiltration and beach face deposition/erosion for the coarse beaches, while in/exfiltration has a slight effect on sediment transport for fine beaches. The model is capable of simulating the short-term evolution of foreshore profile changes, and beach 
watertable and saltwater wedge movement due to interactions between wave motion and coastal groundwater.

Keywords: Beach profile changes; Field-scale simulations; Groundwater exchange;

Intermediate beach, Dissipative beach; Saltwater wedge; Variable-density flow; Wave breaking, RANS

\section{Abbreviations}

ADE

GWT

NS

RANS

SWL

TKE

TVD

VOF

\section{Nomenclature}

Variable

$d$

$D_{50}$

g

$H$
Advection-Dispersion Equation

Groundwater table

Navier-Stokes

Reynolds-Averaged Navier-Stokes

Still Water Level

Turbulent Kinetic Energy

Third-order Variational Diminishing

Volume-Of-Fluid

Description

Dimensions

Local still water depth

L

$50^{\text {th }}$ percentile of the sediment diameter distribution

L

Gravitational acceleration

$\mathrm{LT}^{-2}$

Water wave height

$\mathrm{L}$ 


$\begin{array}{llc}H_{b} & \text { Wave breaking height } & \mathrm{L} \\ L & \text { Wave length } & \mathrm{L} \\ t & \text { Time } & \mathrm{T} \\ T & \text { Wave period } & \mathrm{T} \\ \text { Greek } & & \\ \beta & \text { Local beach slope } & \mathrm{LL}^{-1} \\ \rho & \text { Fluid density } & \mathrm{ML}^{-3} \\ \zeta & \text { Surf similarity parameter } & - \\ \xi & \text { Surf scaling parameter } & -\end{array}$

\section{Introduction}

Most previous investigations concerned with modeling of interactions between ocean water and coastal groundwater focused on tide-induced watertable fluctuations, neglecting high-frequency wave-induced oscillations and variable-density groundwater flow (e.g., Teo et al., 2003; Brovelli et al., 2007; Robinson et al., 2007b, 2009; Slooten et al., 2010; Li et al., 2001, 2007; Xin et al., 2010). However, given the interplay of mechanisms inherent in coastal processes - mixing of fresh- and seawater driven by waves, sediment transport and beach profile changes - it is not possible to extrapolate readily existing results to realistic coastal zone behavior.

Waves in the nearshore zone are an important forcing on sediments and groundwater behavior. While waves induce instantaneous pore water flows below the beach face in response to individual bores and wave runup, these high frequency flows are rapidly 
attenuated (Horn, 2006). As waves break, the resulting energy dissipation and changes in the onshore component of the radiation stresses induce an onshore upward tilt in the mean sea level. This creates (phase-averaged) hydraulic gradients on the beach surface, which result in seawater infiltrating the upper part of the beach and exiting the beach groundwater system near the wave-breaking point (Li et al., 2004; Mao et al., 2006a; Xin et al., 2010). The two-dimensional numerical simulations of Li and Barry (2000) showed that this circulation was affected by the beach groundwater table elevation relative to the Still Water Level (SWL). However, these studies, like numerous other studies on coastal aquifer behavior (e.g., Parlange et al., 1984; Barry et al., 1996; Li et al., 1999, 2000a,b, 2001, 2002b; Jeng et al., 2002, 2005a,b), ignored density variations of pore water and associated densitydependent flows in the beach aquifer. The extent of seawater intrusion into fresh groundwater depends on the sea level, the tidal range of coastal waters, wave cycle, the groundwater recharge rate, and the porosity and sediment composition of the intertidal area. In the nearshore zone with highly dynamic oceanic forcing, mixing zones may form a salty layer above the fresh aquifer water due to wave runup (Barry and Parlange, 2004; Li et al., 2004). Advanced and comprehensive process-based numerical models are required to address directly the interacting processes involved.

One major mechanism for transport and circulation of coastal contamination in beach areas is high and low frequency seabed water pressure oscillations in the surf and swash zones that produce infiltration and exfiltration across the seabed (Bakhtyar et al., 2009a). In/exfiltration can impact on surf and swash zone processes such as nearshore hydrodynamics, momentum exchange and sediment transport. In/exfiltration across the beach face is not well understood, and so there is a need for further investigation into the details of this type of flow and its effects on beach morphology (Horn et al., 2007). Most previous numerical investigations focused on wave motion on impermeable beds and 
neglected the effect of in/exfiltration. However, a mechanistic understanding of the nearshore environment needs to account for interactions of seawater and beach groundwater (Horn, 2006), in particular the role of oceanic motion on sediment transport, foreshore profile changes and salinity distribution.

Numerous researchers have carried out theoretical calculations and field and laboratory experiments to study the interaction of ocean, coastal groundwater, sediment and salt transport (Li et al., 2002; Lee et al., 2007; Bakhtyar et al., 2011). Three different approaches have been used to compute these processes driven by oceanic forcing (Robinson et al., 2009): (i) field experiments; (ii) laboratory measurements; and (iii) numerical simulations. Austin and Masselink (2006a,b) studied hydrodynamics, morphological change and sediment transport on a gravel beach, and concluded that infiltration has important consequences for morphological changes. Lee et al. (2007) studied experimentally the effects of groundwater level on the profile changes in a gravel beach and showed that berm moves up the beach as the groundwater level decreases. Sediment deposition is usually enhanced when the level of the beach watertable is lower than the SWL, while a higher groundwater level increases beach erosion, as has been shown in laboratory experiments (Li et al., 2002a; Bakhtyar et al., 2011). In/exfiltration affects nearshore zone sediment transport due to effective weight modification and boundary layer thickening or thinning (Turner and Masselink, 1998). Ataie-Ashtiani et al. (1999) developed a numerical model to study the effects of tidal fluctuations on groundwater, including the presence of a seepage face and the unsaturated zone. They showed that the effect of beach slope is important for predicting the watertable elevation. Recent field observations from exposed coasts have shown that wave forcing can also have a non-negligible impact on aquifer circulation (Cartwright et al., 2004b), which in turn may affect sediment transport and beach profile changes. Additional discussion of the mathematical modeling approaches 
that have been used to simulate beach aquifers and their interaction with nearshore motion were summarized by Horn (2006) and Bakhtyar et al. (2009a).

Most numerical models that have been used to compute wave motions with a permeable bed are based on the Boussinesq and the non-linear shallow water equations (Masselink and Li., 2001; Li et al., 2002a; Karambas, 2006; Hoque and Asano, 2007). Bakhtyar et al. (2011) have shown that more realistic Reynolds-Averaged Navier-Stokes (RANS) equations can be used instead. Moreover, the sediment transport models that have been used in previous studies have a certain validity range. Existing models do not resolve all potentially important details of groundwater flow and sediment transport, such as wave asymmetry effects, percolation, different wave characteristics and beach profile changes. Bakhtyar et al. (2011) developed a two-dimensional (cross-shore) process-based model for simulating wave motion on a permeable beach taking into account wave-aquifer interactions to investigate the effects of an unconfined coastal aquifer on beach profile evolution, and wave shoaling on the watertable. They computed nearshore hydrodynamic

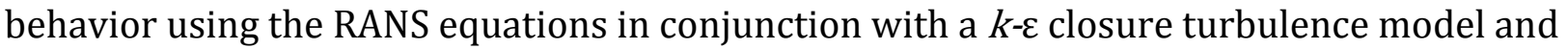
the Volume-Of-Fluid (VOF) technique. Bed morphological changes were calculated using an empirical sediment transport formula that accounts for the influence of fluxes across the beach face. Aquifer hydrodynamics and the interactions between the fresh groundwater and the coastal waves were modeled using a groundwater flow model, although density dependence was not considered.

The aim of this work is to extend further the capabilities of the model presented by Bakhtyar et al. (2011) to include density-dependent groundwater flow. The model is used to evaluate the importance of hydrodynamic parameters - including wave height, wave period and porous media characteristics - on beach face morphology and beach aquifer dynamics (both fresh and seawater) in a field-scale setup. The model has not been validated 
against experimental data since no suitable data sets are available currently. On the other hand, the predictive capabilities of the each sub-module have been tested: The variabledensity groundwater flow model and the setup used to represent the cross-shore section of the aquifer were validated using experimental data collected at the field- and laboratory scales, see for example Brovelli et al. (2006) and Robinson et al. $(2008,2009)$. Validation of the nearshore hydrodynamic and sediment transport module can be found in Bakhtyar et al. (2009b). Finally, the coupled model was validated using a detailed set of experimental data collected in a wave simulator, and the comparison reported by Bakhtyar et al. (2011). Good agreement was found considering different conditions, in particular watertable elevations and properties of the porous medium. Thus, the model used in this study is, at least, partially validated. Specific objectives of this study are to investigate the: (i) beach groundwater response to wave motion and variable flow fields; (ii) beach profile evolution due to different wave conditions and porous media; (iii) effects of wave forcing on variabledensity groundwater behavior; and (iv) effects of in/exfiltration on foreshore profile changes and groundwater dynamics in the nearshore zone.

\section{Model description}

\subsection{Simulation of high-frequency wave motion and beach morphology}

The hydrodynamic model, consisting of the two-dimensional continuity and momentum formulations of the incompressible RANS equations, $k-\varepsilon$ turbulence closure and VOF method, was outlined by Bakhtyar et al. (2011).

The sediment transport model was discussed in detail in Bakhtyar et al. (2011). The surf and swash regions are highly complex, and none of the existing sediment models using the empirical approach gives satisfactory results when applied to permeable beaches. Reviews of sediment transport on permeable beaches indicated that two competing 
processes are important in altering the uprush and backwash transport through infiltration-exfiltration, namely (i) stabilization or destabilization of the surface layers, and (ii) boundary layer thickening or thinning (Butt et al., 2001; Bakhtyar et al., 2009). A modified Shields parameter with extra terms must be used to account for these processes. In the present study, the sediment transport was computed using the modified Meyer-Peter and Muller formula including the infiltration and exfiltration effects (Turner and Masselink, 1998; Butt et al., 2001). In/exfiltration fluxes induce variations in the pressure on the bed surface (lift force), the effective weight, and the normal and shear stress on the bed sediment particles. We therefore used a modified Shields parameter that incorporates the effects of through-bed flow on the sediment transport, following Turner and Masselink (1998) and Butt et al. (2001). This type of formula gives reasonable predictions especially when the grain size is rather large, making it suitable for swash flows. This enables the investigation and analysis of morphology under breaking, overturning, uprush and backwash of waves on the beach slope. In short, it is evident that this model can be employed to model surf/swash zone sediment transport processes. The approach adopted in this investigation was motivated by the success of various studies employing a similar methodology (Karambas and Koutitas 2002; Karambas 2006; Pedrozo-Acuña et al., 2006, 2007). The model for beach profile changes is identical to that of Bakhtyar et al. (2011).

\subsection{Variable-density groundwater flow}

SEAWAT-2000 (Guo and Langevin, 2002) was used to model variable-density beach aquifer behavior. It is a commonly used (e.g., Langevin and Guo, 2006; Li et al., 2009) USGS computer code that couples MODFLOW-2000 (Harbaugh et al., 2000) for groundwater flow and MT3DMS (Zheng and Wang, 1999; Prommer et al., 2001) for solute transport. The model uses the equivalent freshwater head formulation of the groundwater flow equation. 
SEAWAT-2000 uses a finite difference cell-centered numerical scheme to solve the groundwater flow equation, while several options are available to solve the ADE. In all the simulations presented in this work, the Third-order Variational Diminishing (TVD) method was used because it is robust and accurate (Zheng and Wang, 1999).

\subsection{Model interactions}

The three processes, namely (i) wave motions in the cross-shore direction (e.g., wave shoaling, wave breaking, runup/down), (ii) sediment transport and the resulting beach morphology, and (iii) variable-density groundwater flow and solute re-distribution were coupled using a sequential approach (Bakhtyar et al., 2011):

- $\quad$ The groundwater flow model and solute transport were run for $1 \mathrm{y}$ using the sea SWL to set-up a realistic saltwater wedge.

- The hydrodynamic model (wave-motion simulator) was run to produce the freesurface elevation above the beach aquifer for the whole simulation period. The results were applied at the beach-ocean interface in order to simulate the effects of oceanic forcing and to determine the boundary conditions for the other models.

- $\quad$ The heads above the beach face and toe were taken from the hydrodynamic model. Constant head conditions were set at the sea- and landward boundaries, while a noflow boundary condition was assumed at the bottom edge.

- Inputs to the sediment transport and morphology module were the nearshore hydrodynamic conditions (velocities, water elevations, wave height, wavelength, wave period, and turbulence characteristics) and the fluxes across the beach face (infiltration and exfiltration). These were calculated using the head distribution near the beach face obtained from the variable-density groundwater flow model.

A detailed description of the coupling procedure was given by Bakhtyar et al. (2011). 


\section{Results and Discussion}

The geometry of the experimental set-up used to validate the model of Bakhtyar et al. (2011) is not representative of realistic conditions near the shoreline. In particular, the groundwater response for that case might be affected by the shallow impermeable boundary at the bottom of the beach slope and the relatively short distance between the beach face and the landward constant head boundary. Density-dependent aquifer flow was ignored also. On the other hand, the predicted profile changes are probably less affected by the model set-up since erosion is controlled by the ocean circulation in the nearshore area and by the fluxes across the beach face.

\subsection{Model setup}

To investigate the groundwater hydrodynamics subjected to the influence of waves, a suite of numerical experiments was performed using a more realistic set-up. A sketch of the model is shown in Fig. 1. The model simulates a $10-\mathrm{m} \times 50-\mathrm{m}$ cross-section of the shoreline, with a sandy beach aquifer and a 1:10 uniform beach slope. The nearshore free water was 1-m deep (under the SWL), and two wave series with heights of $0.15 \mathrm{~m}$ and $0.25 \mathrm{~m}$ and periods of $2 \mathrm{~s}$ and $4 \mathrm{~s}$ were simulated. The aquifer was unconfined, homogeneous and isotropic with a saturated hydraulic conductivity of $1.5 \mathrm{md}^{-1}$ and $15 \mathrm{md}^{-1}$ for fine and coarse beaches, respectively (Bear, 1972). In the groundwater flow model, the coastal free-water zone was approximated using high hydraulic conductivity $\left(10^{6} \mathrm{md}^{-1}\right)$ and unit porosity. The sand grain density was $2.65 \times 10^{3} \mathrm{kgm}^{-3}$, the beach porosity was 0.4 while the longitudinal and transverse dispersivities were 0.2 and $0.02 \mathrm{~m}$, respectively. A freshwater density of $10^{3}$ $\mathrm{kgm}^{-3}$ was used for the aquifer, and $1.025 \times 10^{3} \mathrm{kgm}^{-3}$ for the seawater. A vertical interface at $x=30 \mathrm{~m}$ between salt- and freshwater (not drawn in Fig. 1) was used as initial condition in all cases, to speed-up the formation of a realistic saline wedge. For each beach type, 
experiments were run considering two groundwater tables (GWT) at the landward boundary: $1.5 \mathrm{~m}$ higher and lower than the SWL, in order to simulate high and low groundwater levels. A higher landward watertable was selected because under natural conditions the groundwater level is higher than SWL and freshwater flows towards the sea, while the lower watertable was used in order to analyze the important case of groundwater pumping that decreases the watertable level and allows saltwater to be drawn into the freshwater aquifer (Barlow, 2003). This case is additionally important as it results in seawater beneath the beach face and in most of the aquifer, and corresponds (except for the change in density) to the uniform density simulation of Bakhtyar et al. (2011). Table 1 summarizes the properties of each of the 12 cases considered, where $H$ is the wave height, $T$ is the wave period, and $\xi$ is the surf scaling parameter (Guza and Inman, 1975).

In Section 3.2, the focus is on the simulated salinity distribution and seawater wedge in the beach aquifer, while in Section 3.3 the aquifer dynamics and the response of beach groundwater to waves are presented and discussed. Infiltration and exfiltration fluxes across the beach face for the different conditions studied are reported in Section 3.4, while beach profile predictions for two types of beach (intermediate and dissipative beaches) and of wave breaker (spilling and plunging breakers) are presented and discussed in Section

\section{5.}

\subsection{Salinity distribution}

The position of salt-freshwater interface was calculated as it varied with hydraulic conductivity and wave characteristics. In Figs. 2 and 3, the salinity distribution and seawater wedge within the aquifer for the coarse and fine sand beaches after $15 \mathrm{~min}$ simulation time with waves are presented. In general, the beach profile went through rapid changes within the first few minutes and a pseudo-steady state was reached after 13 
minutes. Figures 2 and 3 illustrate the normalized salt concentration in the nearshore aquifer for the two landward GWTs: (a) lower (cases 1 and 2, Table 1) and (b) higher (cases 3 and 4, Table 1) watertable levels. For the lower watertable, the saltwater wedge moved landward and invaded completely both coarse and fine sand aquifers, as expected. This is due to the higher hydraulic head on the seaside compared to the groundwater head. For the higher watertable, the flow direction in the aquifer was mainly seaward due to the associated increase in hydraulic gradient, and a small saltwater wedge developed.

The numerical results showed that the saltwater wedge positions for different wave characteristics (e.g., height and period) were the same, so these plots were not included. It follows that the more important factors determining the salt-freshwater interface position are the hydraulic conductivity of the beach and the difference between the SWL and the inland watertable elevation.

\subsection{Beach groundwater dynamics}

Watertable elevation in the aquifer for the case of the inland watertable level higher than the SWL, and under the different wave heights and wave periods (cases 3, 4, 7, 8, 11 and 12) are shown in Fig. 4. The figure shows the results for the coarse and fine sand beaches. The maximum difference occurs near the beach face, where the vertical flow magnitude is highest (results not shown). The change in the head distribution in the coarse sand beach is generally slightly higher than that in the fine sand, as noted by Bakhtyar et al. (2011). As the hydraulic conductivity of the coarse sand is higher than that of fine sand, the groundwater response to wave motion is larger in the former. The numerical results for both fine and coarse and beaches indicate that the watertable level increases as the wave height or wave period increases. This occurs since for the higher wave height and longer 
wave period the water exchange and infiltration rate across the beach face are higher (Fig. 8).

Figure 5 plots the phase-averaged (over three wave cycles) flow fields and salinity distributions in the nearshore aquifer for the coarse sand beaches for the higher and lower watertable levels, and under different wave heights and wave periods: cases 1 and 3 ( $H=$ $0.15 \mathrm{~m}, T=2 \mathrm{~s}), 5$ and $7(H=0.25 \mathrm{~m}, T=2 \mathrm{~s}), 9$ and $11(H=0.15 \mathrm{~m}, T=4 \mathrm{~s})$. Phaseaveraged flow velocity fields for the fine sand beaches, and for the higher and lower boundary water levels, are shown in Fig. 6 for different wave heights and wave periods (cases 2, 4, 6, 8, 10 and 12). Overall, the flow fields in the subsurface show significant complexity, although qualitative similarities are also present, the behavior of which will be discussed further below. The simulation results for these cases show different behavior compared with similar plots of Bakhtyar et al. (2011, Figs. 10, 11). In Fig. 5, the flow field differs significantly among the twelve cases, whereas in the smaller domain considered by Bakhtyar et al. (2011) the hydrodynamics were similar regardless of the groundwater elevation and the hydraulic conductivity, with four convective cells clearly visible. The circulation patterns of the field-scale scenario are instead more complex. For example, in the lower and higher-level scenarios and for different wave conditions, the number of circulation cells visible in the case with low hydraulic conductivity (Fig. 6) is more than for the coarse sand cases (Fig. 5). In addition, for the higher watertable (lower panels of Figs. 5 and 6), the circulation pattern differs from the lower watertable (upper panels of Figs. 5 and 6). As the hydraulic conductivity within the coarse sand beaches is larger than that within the fine sand beaches, water infiltrates deeper into the former and has a larger influence on the circulation in the aquifer.

The wave motion induces a spatially complex response below the beach zone up to the point of maximum runup. Below the beach near the maximum wave runup (near $x \approx 30 \mathrm{~m}$ ), 
the wave set-up produces landward and seaward hydraulic gradients, which interact locally with the near-surface part of the aquifer. As seen in the figure, the net result is a complex pattern of infiltration and exfiltration. For the lower watertable cases (upper panels of Figs. 5 and 6), near the maximum uprush in the swash zone (located at a distance of about $30 \mathrm{~m}$ in the model configuration), the infiltrating water below the beach face splits and part moves landward and mixes with the ambient groundwater, and part moves seaward. Lower down the beach face, local circulation cells form. At the wave-breaking point (located at a distance of about $35 \mathrm{~m}$ ), two circulation cells converge in all the simulations. In this region the water from the underlying aquifer is discharged. For the higher watertable cases (lower panels of Figs. 5 and 6), the numerical results show the water circulation below the beach due to wave set-up and water exfiltration occurs at the upper part of the swash zone near the maximum runup (near $x \approx 30 \mathrm{~m}$ ), while infiltration takes place near $x \approx 32 \mathrm{~m}$ for all cases. These findings are consistent with previous investigations (e.g., Li and Barry, 2000; Bakhtyar et al., 2011).

\subsection{Water exchange and in/exfiltration rates on the beach face}

Figure 7 shows the phase-averaged in/exfiltration rates for the lower and higher watertables on the coarse (case $1, H=0.15 \mathrm{~m}, T=2 \mathrm{~s}, \mathrm{GWT}=5.5 \mathrm{~m}$, and case $3, H=0.15$ m, $T=2 \mathrm{~s}, \mathrm{GWT}=8.5 \mathrm{~m}$, Fig. $7 \mathrm{a}$ ) and fine (case $2, H=0.15 \mathrm{~m}, T=2 \mathrm{~s}, \mathrm{GWT}=5.5 \mathrm{~m}$ and case $4, H=0.15 \mathrm{~m}, T=2 \mathrm{~s}, \mathrm{GWT}=8.5 \mathrm{~m}$, Fig. $7 \mathrm{~b}$ ) sand beaches. The in/exfiltration rates across the beach face show that the maximum infiltration takes place at the upper part of the runup, while exfiltration is the largest near the breaking point $(x \approx 35 \mathrm{~m}$, panels a and b). The positions of maximum in/exfiltration are also consistent with the flow patterns and phase-averaged velocities in the nearshore aquifer (Figs. 5 and 6). Panel a (cases 1 and 3) of

Fig. 7 shows that, on the coarse sand beach, in the case of a lower watertable and at the maximum uprush, significant infiltration takes place across the beach face, with no 
exfiltration at the lower part of the swash zone. In contrast to case 1 , much more exfiltration takes place with the higher watertable (panel a, case 3) in the upper part of swash zone. The results in panel b show that, in the case of a lower watertable (case $2, H=0.15 \mathrm{~m}, T=2$ $\mathrm{s}, \mathrm{GWT}=5.5 \mathrm{~m})$, near the maximum uprush strong infiltration occurs on the beach face while drainage occurs at the lower part of the swash zone. On the contrary, no infiltration takes place under high watertable conditions (case $4, H=0.15 \mathrm{~m}, T=2 \mathrm{~s}, \mathrm{GWT}=8.5 \mathrm{~m}$ ) in the upper part of the swash zone. Not surprisingly, the magnitude of the maximum exfiltration for the higher watertable elevation is higher (panel b, case 4) than for the lower watertable case (panel b, case 2), while infiltration shows the opposite behavior.

The net exchange (infiltration or exfiltration) rate across the beach surface was calculated by integrating the averaged in/exfiltration rates. Depending on the watertable elevation, net infiltration or exfiltration can result. For the coarse sand, the net exchange rates of high (case $3, H=0.15 \mathrm{~m}, T=2 \mathrm{~s}, \mathrm{GWT}=8.5 \mathrm{~m}$ ) and low (case $1, H=0.15 \mathrm{~m}, T=2$ $\mathrm{s}, \mathrm{GWT}=5.5 \mathrm{~m}$ ) watertable levels were $11.52 \mathrm{~m}^{2} \mathrm{~d}^{-1}$ and $-7.8 \mathrm{~m}^{2} \mathrm{~d}^{-1}$, respectively (negative values for infiltration). The net rate for fine sand; and for the cases of high (case $4, H=0.15$ $\mathrm{m}, T=2 \mathrm{~s}, \mathrm{GWT}=8.5 \mathrm{~m}$ ) and low (case $2, H=0.15 \mathrm{~m}, T=2 \mathrm{~s}, \mathrm{GWT}=5.5 \mathrm{~m}$ ) watertables are $0.005 \mathrm{~m}^{2} \mathrm{~d}^{-1}$ and $-0.061 \mathrm{~m}^{2} \mathrm{~d}^{-1}$, correspondingly. These results show that the net exchanges for the low and high watertable cases (for both coarse and fine sands) are infiltration and exfiltration, respectively. These results are in agreement with existing understanding of water exchange between ocean and beach aquifer (Horn, 2006). This trend shows the different roles of the watertable level on the water exchange and in/exfiltration rates on the beach face. Furthermore, panels a and b of Fig. 7 and the above values show that the rate of in/exfiltration in the coarse sand beach is much higher than that in the fine sand beach, as would be expected due to the differing $K$ values. 
Simulated time-averaged in/exfiltration rates on the beach face for the higher watertable levels and under the various wave heights and wave periods (cases 3, 4, 7, 8, 11 and 12) are shown in Fig. 8, while Fig. 9 shows the same results for the lower watertable levels (cases 1, 2, 5, 6, 9 and 10). The upper and lower panels show results for the coarse and fine sand beaches, respectively. Similarly to the results shown in Fig. 7, the highest aquifer recharge rate occurs at the upper part of swash zone, while the highest discharge rates occur in the vicinity of wave breaking on the beach face. For both beach types, for a low watertable, a considerable amount of seawater enters the aquifer due to the increase in hydraulic head on the seabed accompanying the wave height increase (Fig. 9). The results show that the higher wave height gives the largest rate of average in/exfiltration in the nearshore area. The magnitude of the peak infiltration rate for the maximum wave height is approximately $20-60 \%$ higher than the other cases, while for exfiltration it is approximately $10-40 \%$ higher. For the coarse sand and higher watertable, the net exchange rates of cases 7 (high wave height, $H=0.25 \mathrm{~m}, T=2 \mathrm{~s}, \mathrm{GWT}=8.5 \mathrm{~m}$ ) and 11 (long wave period, $H=0.15$ $\mathrm{m}, T=4 \mathrm{~s}, \mathrm{GWT}=8.5 \mathrm{~m}$ ) are $13.93 \mathrm{~m}^{2} \mathrm{~d}^{-1}$ and $7.62 \mathrm{~m}^{2} \mathrm{~d}^{-1}$, respectively. For the coarse sand and lower watertable, the net exchange rates of cases 5 (high wave height, $H=0.25 \mathrm{~m}, T=$ $2 \mathrm{~s}, \mathrm{GWT}=5.5 \mathrm{~m}$ ) and 9 (long wave period, $H=0.15 \mathrm{~m}, T=4 \mathrm{~s}$, GWT $=5.5 \mathrm{~m}$ ) are -13.42 $m^{2} d^{-1}$ and $-12.40 m^{2} d^{-1}$, correspondingly. The net rate for fine sands and for higher watertable (case $8, H=0.25 \mathrm{~m}, T=2 \mathrm{~s}, \mathrm{GWT}=8.5 \mathrm{~m}$, and case $12, H=0.15 \mathrm{~m}, T=4 \mathrm{~s}$, GWT $=8.5 \mathrm{~m})$ are $-0.02 \mathrm{~m}^{2} \mathrm{~d}^{-1}$ and $-0.007 \mathrm{~m}^{2} \mathrm{~d}^{-1}$, correspondingly; while net rate for fine sand and lower watertable (case $6, H=0.25 \mathrm{~m}, T=2 \mathrm{~s}, \mathrm{GWT}=5.5 \mathrm{~m}$, and case $10, H=0.15$ $\mathrm{m}, T=4 \mathrm{~s}, \mathrm{GWT}=5.5 \mathrm{~m})$ are $-0.18 \mathrm{~m}^{2} \mathrm{~d}^{-1}$ and $-0.08 \mathrm{~m}^{2} \mathrm{~d}^{-1}$, respectively. Therefore, a relatively large amount of water is discharged to the sea under the maximum wave height conditions (cases 5-8). These results illustrate that the wave height is a more important parameter for the water exchange at beach face than the other wave parameters. As wave 
setup mainly dependent on wave height, the water exchange across the beach face reflects the wave setup. However, Figs. 8 and 9 show that the maximum uprush under the longer wave period $(x=28.2 \mathrm{~m}$ ) is larger than the maximum runup under the higher wave height $(x=28.6 \mathrm{~m})$ condition. It is evident that this difference, which potentially gives more opportunity for seawater to penetrate the beach, is insufficient for wave period to supplant wave height as the main factor controlling infiltration into the beach.

\subsection{Morphodynamics of coarse and fine sand beaches for different wave characteristics}

As surf and swash zones are dynamic areas where a number of inter-connected processes happen, the beach face morphodynamics are affected continuously by sediment transport resulting from wave shoaling and breaking, and interactions between the seawater and coastal groundwater. Figure 10a illustrates the predicted foreshore profile changes after reaching an equilibrium state for the coarse sand beaches and for the two landward groundwater table elevations (cases 1 and 3). On the coarse sand beach, accretion happens in the upper part of swash zone, while erosion takes place in the lower part (e.g., below the interaction of SWL with beach). The results demonstrate that the biggest berm above the SWL occurs when the watertable level is lower than the SWL (case 1). Generally, as the watertable is lowered, the berm shifts landward, and vice versa. In the lower watertable condition, the infiltration rate is higher and induces larger stabilization than that with the higher watertable. For coarse sand, infiltration results in a steeper foreshore beach profile and in a larger berm. For this reason, the steepest beach face is obtained for the case with lowest watertable (Fig. 10a, case 1). Here, we present also the in/exfiltration rate for case 3 in order to show the connection between the morphology observed and in/exfiltration rate. As shown in Fig. 10a, there is a correlation between position of maximum in/exfiltration and position of maximum deposition/erosion for the coarse sand beaches. This illustrates that the water flux across the beach face is an important factor for 
nearshore sediment transport and coarse beach stability. Even on an impermeable beach, uprush and backwash volumes on the beach face are asymmetric due to swash-swash interaction. In/exfiltration on a permeable beach additionally affects the flow asymmetry in the swash zone by decreasing the rundown strength and duration, and thereby enhances onshore sediment transport (Masselink and Li, 2000).

Simulated beach profiles on the fine sand beach for different groundwater elevations in the nearshore zone are presented in Fig. 10b (cases 2 and 4). In contrast to the coarse sand beach cases (where sediment transport behavior is accretive), Fig. 10b shows that, on the fine sand beach, sediment transport behavior is erosive and mostly in the offshore direction. For fine sand beaches, the limited infiltration leaves available more backrush water, leading to seaward transport of the entrained sediment. In the swash zone, as the infiltration flux is low, dissipation of wave energy is very low and increased runup moves sediments towards the sea. As the erosion takes place above the intersection of the SWL with the beach face, the bars further develop offshore, resulting in a wider surf zone and flatter beach profile than for coarse sand. A comparison between the beach profiles on the fine sand beach for different groundwater elevations reveals negligible variation. So, in/exfiltration has at most a slight effect on sediment transport in the swash zone of fine beaches and other factors such as grain size and wave characteristics are dominant in controlling the beach profile change. Generally, erosion is greater on the coarse (as opposed to the fine) sand beach seaward of the swash zone (near $x \approx 33 \mathrm{~m}$ ) and below the SWL. Correspondingly, berm is greater on the coarse beach.

A comparison of panels a and b of Fig. 10 illustrates that, because of the higher permeability, a much greater infiltration flux into the aquifer occurs in the coarse sand beach (Fig. 7a,b), consequently reducing the swash and increasing the stabilizing force on the sediments (via increasing the effective weight). In addition, the return flow (undertow) 
moved coarse sediments offshore much less than for the fine sand beach due to the higher settling velocity of coarse sand relative to fine sand (Bakhtyar et al., 2011). Greater onshore sediment transport occurs on a coarse sand beach than on a fine sand beach under the same wave conditions. In both fine and coarse beaches, when the watertable is higher than the SWL (cases 3, 4, 7, 8, 11 and 12), the beach allows a much greater exfiltration flux.

Exfiltration decreases the shear stress at the bed, enhancing bed fluidization (by decreasing the effective weight) and destabilizing the bed by exerting an upward force on sediments. Furthermore, the run-down flow rate above the beach is higher due to less infiltration, and so more sediment is transported. As a result, offshore sediment transport is increased under high watertable conditions.

Results for foreshore profile changes on the beach face for the coarse sand beach for the lower and higher watertable levels and under the different wave heights and wave periods conditions (cases 1, 3, 5, 7, 9 and 11) are shown in Fig. 11, while Fig. 12 reports the same results for the fine sand beach (cases 2, 4, 6, 8, 10 and 12). Figures 11 and 12 indicate that although foreshore profiles for the three wave conditions showed similar behavior for coarse and fine beaches individually, there are significant differences in size and position of bar, berms and eroded parts.

The surf scaling parameter, $\xi$, was used to characterize the type of beach and morphodynamics of the nearshore zone. It is defined as (Guza and Inman, 1975):

$$
\xi=\frac{H_{b}\left(\frac{2 \pi}{T}\right)^{2}}{2|\vec{g}| \tan ^{2} \beta},
$$


where $H_{b}$ is the wave breaking height and $\beta$ is the beach slope. Dissipative conditions occur for $\xi>20$ while intermediate conditions for $2.5<\xi<20$ : Cases 1-4, and 9-12 (cases with longer wave periods) represent dissipative beaches, while cases 5-8 (cases with higher wave heights) are intermediate beaches (see Table 1). As shown in Figs. 11 and 12, the change of foreshore profile in the nearshore zone of intermediate beaches (Figs. 11 and 12 for cases 5-8) is more noticeable (with a larger berm and bar size) than that for the dissipative beaches, as shown in Figs. 11 (cases 1, 3, 9 and 11) and 12 (cases 2, 4, 10 and 12). This is consistent with the reduced magnitude, relative to an intermediate beach, of turbulence, flow velocity, momentum and wave energy after breaking that occurs on dissipative beaches during both the uprush and backwash (Miles et al., 2006). These results are also consistent with the field results of Miles et al. (2006) and the numerical results of Bakhtyar et al. (2010a). They indicated that the sediment transport and concentrations are greater on intermediate beaches than on dissipative beaches. Furthermore, as sediment transport depends on the wave energy (Bakhtyar et al., 2010a,b), where the wave energy flux is proportional to the wave height squared and wave period, higher waves induce a greater sediment flux. It can be observed that, with increasing wave height (cases 5-8), the position of the bar shifts offshore (because the waves break further offshore) and the berm position shifts onshore (because of higher levels of turbulence due to wave breaking and stronger swash motion).

Figures 11 and 12 indicate that the beach profile change for the longer wave period (Figs. 11 and 12, cases 5-8) is greater than that for shorter wave period and same wave height (Figs. 11 and 12, cases 1-4). The surf similarity parameter, $\zeta=\tan \beta(L / H)^{1 / 2}$ (Iribarren and Nogales, 1949), was used to characterize the breaker type in the nearshore zone. For the waves with $H=0.15 \mathrm{~m}$ and $T=2 \mathrm{~s}$, and $H=0.15 \mathrm{~m}$ and $T=4 \mathrm{~s}$, the surf 
similarity parameter values are $\zeta=0.45<0.5$ and $\zeta=0.91>0.5$, respectively, which represent, respectively, (i) a spilling breaker and (ii) a plunging breaker. As the influence of swash-swash interactions becomes proportionally larger for shorter period waves and the turbulence and wave energy under the plunging breaker are much higher than for a spilling breaker (Bakhtyar et al., 2010b), sediment transport and beach profile variations are more important in a plunging breaker.

We considered a comparison of beach profile changes induced by variable density/uniform density conditions. However, numerical simulations showed that infiltration/exfiltration fluxes across the beachface and profile changes were mostly controlled by the wave characteristics and the properties of the medium. The influence of variable-density conditions was in practice negligible for the setup considered in this work.

\section{Concluding Remarks}

A comprehensive process-based model was applied to analyze nearshore hydrodynamics, variable-density groundwater flow, beach face sediment transport, and their interactions at the field scale. A series of numerical experiments demonstrated the model's capacity to evaluate the importance of hydrodynamic parameters (including the wave height and period) and porous media characteristics on beach aquifer dynamics and foreshore morphodynamics. The results indicate that important processes for sediment transport and foreshore evolution during the uprush and backwash cycles are wave characteristics, beach grain size, and the interactions between ocean motion and beach aquifer. This suggests that accurate prediction of beach profile changes is achieved only if the aquifer-wave interactions are taken into account, that is, the impermeable beach assumption is not entirely valid. 
Numerical results show that the permeability of the beach face affects the location of berms and bars in the foreshore area. Generally, coarse sand beaches are steeper than fine beaches (Masselink and Li, 2001). There is a strong correlation between in/exfiltration and beach face deposition/erosion for coarse sand beaches (in/exfiltration contributes to the beach profile changes), while in/exfiltration has a slight effect on sediment transport in the nearshore zone of fine beaches (other factors such as grain size and wave characteristics are have more effect on the morphology). Numerical experiments show that larger wave heights and increased wave periods induce larger sediment transport rates and beach profile changes. Furthermore, sediment transport is greater on intermediate beaches than on dissipative beaches and beach profile variations are greater under plunging breakers. Coarse- and fine-grained beaches differ greatly in their erosive characteristics, as manifested in the locations of bars and berms. The sediment transport flux is offshore for finer sediments and onshore for coarser sediments and is independent of inland watertable height. Therefore, wave characteristics and sediment grain size are critical to beach profile prediction. The saltwater wedges produced are, however, hardly affected by the wave characteristics in the surf and swash zones.

Overall, our analysis shows that, with reasonable hypotheses, it is possible to simulate the foreshore evolution, fresh- and sea-water dynamics subjected to wave motion and nearshore hydrodynamics, consistent with existing understanding of this area.

\section{Acknowledgement}

Support of the Swiss National Foundation (SNF 200021_124780) is acknowledged. 


\section{References}

Ataie-Ashtiani, B., Volker, R.E., Lockington, D.A., 1999. Tidal effects on sea water intrusion in unconfined aquifers. J. Hydrol. 216, 17-31.

Austin, M.J., Masselink, G., 2006a. Observations of morphological change and sediment transport on a steep gravel beach. Mar. Geol. 29, 59-77.

Austin, M.J., Masselink, G., 2006b. Swash-groundwater interaction on a steep gravel beach. Cont. Shelf Res. 26, 2503-2019.

Bakhtyar, R., Barry, D.A., Li, L., Jeng, D.-S., Yeganeh-Bakhtiary, A., 2009a. Modeling sediment transport in the swash zone: A review. Ocean Eng. 36, 767-783.

Bakhtyar, R., Ghaheri, A., Yeganeh-Bakhtiary, A., Barry, D.A., 2009b. Process-based model for nearshore hydrodynamics, sediment transport and morphological evolution in the surf and swash zones. Appl. Ocean Res. 31, 44-56.

Bakhtyar, R., Barry, D.A., Yeganeh-Bakhtiary, A., Ghaheri, A., 2009c. Numerical simulation of surf-swash zone motions and turbulent flow. Adv. Water Resour. 32, 250-263.

Bakhtyar, R., Barry, D.A., Yeganeh-Bakhtiary, A., Li, L., Parlange, J.-Y., Sander, G.C., 2010a. Numerical simulation of two-phase flow for sediment transport in the inner surf and swash zones. Adv. Water Resour. 33, 277-290.

Bakhtyar, R., Razmi, A.M., Barry, D.A., Yeganeh-Bakhtiary, A., Zou, Q.-P., 2010b. Air-water two-phase flow model of turbulent surf and swash zone wave motions. Adv. Water Resour. 33, 1560-1574. 
Bakhtyar, R., Brovelli, A., Barry, D.A., Li, L., 2011. Wave-induced watertable fluctuations, sediment transport and beach profile change: Modeling and comparison with largescale laboratory experiments. Coast. Eng. 58, 103-118.

Barlow, P.M., 2003. Groundwater in freshwater-saltwater environments of the Atlantic coast. U.S. Geological. Survey Circular., 1262. http://pubs.usgs.gov/circ/2003/circ1262/pdf/circ1262.pdf, accessed 21 February 2011.

Barry, D.A., Barry, S.J., Parlange, J.-Y., 1996. Capillarity correction to periodic solutions of the shallow flow approximation. In Mixing Processes in Estuaries and Coastal Seas, C.B. Pattiaratchi (ed.), Coastal and Estuarine Studies, Vol. 50, Am. Geophys. Union, Washington, DC, USA, pp. 496-510.

Barry, D. A., Parlange, J.-Y., 2004. Subsurface pathways of contaminants to coastal waters. Advances in Hydro-Science and -Engineering, Volume VI, M.S. Altinakar, S.S.Y. Wang, K. P. Holz, M. Kawahara (eds). Proceedings of Abstracts and Papers of the 6th International Conference of Hydro-Science and -Engineering, Brisbane, Australia, 31 May - 3 June. 8 pp.

Bear, J. 1972. Dynamics of Fluids in Porous Media, American Elsevier, New York, USA.

Brovelli, A., Mao, X., Barry, D.A., 2007. Numerical modeling of tidal influence on densitydependent contaminant transport. Water Resour. Res. 43, W10426, doi: 10.1029/2006WR005173.

Butt, T., Russell, P., Turner, I., 2001. The influence of swash infiltration-exfiltration on beach face sediment transport: Onshore or offshore? Coast. Eng. 42, 35-52. 
Cartwright, N., Li L., Nielsen, P., 2004a. Response of the salt-freshwater interface in a coastal aquifer to a wave-induced groundwater pulse: Field observations and modeling. Adv. Water Resour. 27, 297-303.

Cartwright, N., Nielsen, P., Li, L., 2004b. Experimental observations of watertable waves in an unconfined aquifer with a sloping boundary. Adv. Water Resour. 27, 991-1004.

Guo, W., Langevin, C.D., 2002. User's guide to SEAWAT: A computer program for simulations of three-dimensional variable density groundwater flow, US Geological Survey, Techniques of Water-Resources Investigations 6-A7, Tallahassee, Florida, USA. http://fl.water.usgs.gov/PDF files/twri 6 A7 guo langevin.pdf, accessed 21 February 2011.

Guza, R.T., Inman, D.L., 1975. Edge waves and beach cusps. J. Geophys. Res. 80, 2997-3012.

Harbaugh, A.W., Banta, E.R., Hill, M.C., McDonald, M.G., 2000. MODFLOW-2000, The US Geological Survey modular ground-water model - User guide to modularization concepts and the groundwater flow process, US Geological Survey Open File Report 00-92, $121 \mathrm{p}$.

http://water.usgs.gov/nrp/gwsoftware/modflow2000/modflow2000.html, accessed 21 February 2011.

Hoque, M.A., Asano, T., 2007. Numerical study on wave-induced filtration flow across the beach face and its effects on swash zone sediment transport. Ocean Eng. 34, 20332044.

Horn, D.P., 2006. Measurements and modeling of beach groundwater flow in the swashzone: A review. Cont. Shelf Res. 26, 622-652. 
Horn, D.P., Baldock, T.E., Li, L., 2007. The influence of groundwater on profile evolution of fine and coarse sand beaches. Proceedings of Coastal Sediments '07, New Orleans, USA, ASCE, pp. 506-519.

Jeng, D.-S., Li, L., Barry, D.A., 2002. Analytical solution for tidal propagation in a coupled semi-confined/phreatic coastal aquifer. Adv. Water Resour. 25, 577-584.

Jeng, D.-S., Barry, D.A., Seymour, B.R., Dong, P., Li. L., 2005a. Two-dimensional approximation for tide-induced watertable fluctuations in a sloping sandy beach. Adv. Water Resour. 28, 1040-1047.

Jeng, D.-S., Seymour, B.R., Barry, D.A., Li, L., Parlange, J.-Y., 2005b. New approximation for free surface flow of groundwater: Capillary correction. Adv. Water Resour. 28, 10321039.

Karambas, T.V., Koutitas, C., 2002. Surf and swash zone morphology evolution induced by nonlinear waves. Journal of Waterway, Port, Coastal, and Ocean Engineering, ASCE $128(3), 101-142$.

Karambas, T.V., 2006. Prediction of sediment transport in the swash zone by using a nonlinear wave model. Cont. Shelf Res. 26, 599-609.

Iribarren, C.R., Nogales, C., 1949. Protection des ports. In: Section II, communication 4, XVIIth international naval congress, Lisbon, Portugal, pp. 31-80.

Langevin, C.D., Guo, W., 2006. MODFLOW/MT3DMS-based simulation of variable-density ground water flow and transport. Ground Water 44, 339-351.

Launder, B.E., Spalding, D.B., 1974. The numerical computation of turbulent flows. Comput. Meth. Appl. Mech. Eng. 3, 269-289. 
Lee, K.H., Mizutania, N., Hur, D.S., Kamiya, A., 2007. The effect of groundwater on topographic changes in a gravel beach. Ocean Eng. 34, 605-615.

Li, H., Jiao, J.J., 2001. Tide-induced groundwater fluctuation in a coastal leaky confined aquifer system extending under the sea. Water Resour. Res. 37,1165-1171.

Li,H., Li,G., Cheng, J., Boufadel, M.C., 2007. Tide-induced head fluctuations in a confined aquifer with sediment covering its outlet at the sea floor. Water Resour. Res. 43, W03404, doi:10.1029/2005WR004724.

Li, L., Barry, D.A., 2000. Wave-induced beach groundwater flow. Adv. Water Resour. 23, 325-337.

Li, L., Barry, D.A., Cunningham, C., Stagnitti, F., Parlange, J.-Y., 2000a. A two-dimensional analytical solution of groundwater responses to tidal loading in an estuary and ocean. Adv. Water Resour. 23, 825-833.

Li, L., Barry, D.A., Jeng, D.-S., 2001. Tidal fluctuations in a leaky confined aquifer: Dynamic effects of an overlying phreatic aquifer. Water Resour. Res. 37, 1095-1098.

Li, L., Barry, D.A., Jeng, D.-S., Prommer, H., 2004. Tidal dynamics of groundwater flow and contaminant transport in coastal aquifers, In Coastal Aquifer Management-Monitoring, Modeling, and Case Studies, A. H.-D. Cheng and D. Ouazar (editors), Chap. 6, Lewis Publishers, Boca Raton, Florida, USA, pp. 115-141.

Li, L., Barry, D.A., Pattiaratchi, C.B., Masselink, G., 2002a. BeachWin: Modeling groundwater effects on swash sediment transport and beach profile changes. Env. Model Softw. 17, 313-320. 
Li, L., Barry, D.A., Stagnitti, F., Parlange, J.-Y., 1999. Submarine groundwater discharge and associated chemical input to a coastal sea. Water Resour. Res. 35, 3253-3259.

Li, L., Barry, D.A., Stagnitti, F., Parlange, J.-Y., Jeng, D.-S., 2000b. Beach water table fluctuations due to spring-neap tides: Moving boundary effects. Adv. Water Resour. $23,817-824$.

Li, L., Dong, P., Barry, D.A., 2002b. Tide-induced water table fluctuations in coastal aquifers bounded by rhythmic shorelines. ASCE J. Hydraul. Eng.. 128, 925-933.

Li, X., Hu, B.X., Burnett, W.C., Santos, I.R., Chanton, J.P., 2009. Submarine ground water discharge driven by tidal pumping in a heterogeneous aquifer. Ground Water 47, 558568.

Mao, X., Enot, P., Barry, D.A., Li, L., Binley, A., Jeng, D.-S., 2006a. Tidal influence on behaviour of a coastal aquifer adjacent to a low-relief estuary. J. Hydrol. 327, 110-127.

Mao, X., Prommer, H., Barry, D.A., Langevin, C.D., Panteleit, B., Li, L., 2006b. Threedimensional model for multi-component reactive transport with variable density groundwater flow. Env. Model Softw. 21, 615-628.

Masselink, G., Li, L., 2001. The role of swash infiltration in determining the beachface gradient: A numerical study. Mar. Geol. 176, 139-156.

Miles, J., Butt, T., Russell, P., 2006. Swash zone sediment dynamics: A comparison of a dissipative and an intermediate beach. Mar. Geol. 231, 181-200.

Meyer-Peter, E., Muller, R., 1948. Formulas for bed-load transport. Proceedings $3^{\text {rd }}$ Meeting of the International Association for Hydraulic Research, Stockholm, Sweden, pp. 3964. 
Parlange, J.-Y., Stagnitti, F., Starr, J.L., Braddock, R.D., 1984. Free-surface flow in porous media and periodic solution of the shallow-flow approximation. J. Hydrol. 70, 251263.

Pedrozo-Acuna, A., Simmonds, D.J., Otta, A.K., Chadwick, A.J., 2006. On the cross- shore profile change of gravel beaches. Coastal Engineering 53(4), 335-347.

Pedrozo-Acuna, A., Simmonds, D.J., Chadwick, A.J.,Silva, R., 2007. A numerical- empirical approach for evaluating morphodynamic processes on gravel and mixed sand-gravel beaches. Marine Geology 241, 1-18.

Prommer, H., Barry, D.A., Zheng, C., 2003. MODFLOW/MT3DMS-based reactive multicomponent transport modeling. Ground Water 41, 247-257.

Robinson, C., Brovelli, A., Barry, D.A., Li. L., 2009. Tidal influence on BTEX biodegradation in sandy coastal aquifers. Adv. Water Resour. 32, 16-28.

Robinson, C., Li, L., Prommer, H., 2007a. Tide-induced recirculation across the aquifer-ocean interface. Water Resour. Res. 43, W07428, doi:10.1029/2006WR005679.

Robinson, C.E., Li, L., Barry, D.A., 2007b. Effect of tidal forcing on a subterranean estuary. Adv. Water Resour. 30, 851-865.

Simpson, M.J., 2004. SEAWAT-2000: Variable-density flow processes and integrated MT3DMS transport processes. Ground Water, 42, 642-645.

Slooten, L.J., Carrera, J., Castro, E., Fernandez-Garcia, D., 2010. A sensitivity analysis of tideinduced head fluctuations in coastal aquifers. J. Hydrol. 393, 370-380. 
Teo, H.T., Jeng, D.-S., Seymour, B.R., Barry, D.A., Li, L., 2003. A new analytical solution for water table fluctuations in coastal aquifers with sloping beaches. Adv. Water Resour. $26,1239-1247$.

Turner, I.L., Masselink, G., 1998. Swash infiltration-exfiltration and sediment transport. J. Geophys. Res. 103, 30813-30825.

Xin, P., Robinson, C., Li, L., Barry, D.A., Bakhtyar, R., 2010. Effects of wave forcing on a subterranean estuary. Water Resour. Res. 46, W12505, doi:10.1029/2010WR009632.

Zheng, C., Wang, M.C., 1999. MT3DMS-A modular three-dimensional multispecies transport model for simulation of advection, dispersion and chemical reactions of contaminant in groundwater systems; documentation and user's guide. US Army Corps of Engineers Contract Report SERDP-99-1, Vicksburg, Mississippi, USA, 169 p. 
Table 1. Characteristics of the waves and groundwater conditions in the numerical experiments.

\begin{tabular}{|c|c|c|c|c|c|c|c|c|}
\hline Case & $\begin{array}{c}H \\
(\mathrm{~m})\end{array}$ & $\begin{array}{c}K_{f} \\
\left(\mathrm{~ms}^{-1}\right)\end{array}$ & $\begin{array}{c}D_{50} \\
(\mathrm{~mm})\end{array}$ & $\begin{array}{c}T \\
\text { (s) }\end{array}$ & $\begin{array}{l}\text { Initial } \\
\text { groundwater } \\
\text { elevation (m) }\end{array}$ & $\xi$ & Beach type & $\begin{array}{c}\text { Net } \\
\text { in/exfiltration } \\
\left(\mathrm{m}^{2} \mathrm{~d}^{-1}\right)\end{array}$ \\
\hline 1 & 0.15 & $10^{-4}$ & 0.84 & 2 & 5.5 & 15.07 & dissipative & -7.8 \\
\hline 2 & 0.15 & $10^{-5}$ & 0.197 & 2 & 5.5 & 15.07 & dissipative & -0.06 \\
\hline 3 & 0.15 & $10^{-4}$ & 0.84 & 2 & 8.5 & 15.07 & dissipative & 11.52 \\
\hline 4 & 0.15 & $10^{-5}$ & 0.197 & 2 & 8.5 & 15.07 & dissipative & 0.005 \\
\hline 5 & 0.25 & $10^{-4}$ & 0.84 & 2 & 5.5 & 25.1 & intermediate & -13.42 \\
\hline 6 & 0.25 & $10^{-5}$ & 0.197 & 2 & 5.5 & 25.1 & intermediate & -0.18 \\
\hline 7 & 0.25 & $10^{-4}$ & 0.84 & 2 & 8.5 & 25.1 & intermediate & 13.93 \\
\hline 8 & 0.25 & $10^{-5}$ & 0.197 & 2 & 8.5 & 25.1 & intermediate & -0.02 \\
\hline 9 & 0.15 & $10^{-4}$ & 0.84 & 4 & 5.5 & 3.77 & dissipative & -12.40 \\
\hline 10 & 0.15 & $10^{-5}$ & 0.197 & 4 & 5.5 & 3.77 & dissipative & 0.08 \\
\hline 11 & 0.15 & $10^{-4}$ & 0.84 & 4 & 8.5 & 3.77 & dissipative & 7.62 \\
\hline 12 & 0.15 & $10^{-5}$ & 0.197 & 4 & 8.5 & 3.77 & dissipative & -0.007 \\
\hline
\end{tabular}




\section{Figure Captions}

Fig. 1. Schematic illustration of the configuration of the numerical model used for the fieldscale simulations.

Fig. 2. Normalized salt concentration in the nearshore aquifer for the coarse sand beach for

(a) lower, case $1(H=0.15 \mathrm{~m}, T=2 \mathrm{~s}, \mathrm{GWT}=5.5 \mathrm{~m})$; and (b) higher, case $3(H=0.15$

$\mathrm{m}, T=2 \mathrm{~s}, \mathrm{GWT}=8.5 \mathrm{~m})$, watertable levels.

Fig. 3. Normalized salt concentration in the nearshore aquifer for the fine sand beach for the

(a) lower, case $2(H=0.15 \mathrm{~m}, T=2 \mathrm{~s}, \mathrm{GWT}=5.5 \mathrm{~m})$; and (b) higher, case $4(H=0.15$

m, $T=2 \mathrm{~s}, \mathrm{GWT}=8.5 \mathrm{~m})$, watertable levels.

Fig. 4. Watertable elevations for the higher watertable levels (GWT $=8.5 \mathrm{~m}$ ) and under different wave heights and wave periods (cases $3,4(H=0.15 \mathrm{~m}, T=2 \mathrm{~s}), 7,8(H=$ $0.25 \mathrm{~m}, T=2 \mathrm{~s}), 11$ and $12(H=0.15 \mathrm{~m}, T=4 \mathrm{~s}))$.

Fig. 5. Simulated flow fields and salinity distributions in the nearshore aquifer for the coarse sand beaches, (a) cases 1 and $3(H=0.15 \mathrm{~m}, T=2 \mathrm{~s})$; (b) cases 5 and $7(H=0.25 \mathrm{~m}, T$ $=2 \mathrm{~s})$; and (c) cases 9 and $11(H=0.15 \mathrm{~m}, T=4 \mathrm{~s})$. Upper panels: lower watertable $(\mathrm{GWT}=5.5 \mathrm{~m})$. Lower panels: higher watertable $(\mathrm{GWT}=8.5 \mathrm{~m})$.

Fig. 6. Simulated flow fields and salinity distributions in the nearshore aquifer for the fine sand beaches, (a) $H=0.15 \mathrm{~m}, T=2 \mathrm{~s}$, cases 2 and 4 ; (b) $H=0.25 \mathrm{~m}, T=2 \mathrm{~s}$, cases 6 and 8; and (c) $H=0.15 \mathrm{~m}, T=4 \mathrm{~s}$, cases 10 and 12. Upper panels: lower watertable $(\mathrm{GWT}=5.5 \mathrm{~m})$. Lower panels: higher watertable $(\mathrm{GWT}=8.5 \mathrm{~m})$.

Fig. 7. Phase-averaged in/exfiltration rates on the beachface for the lower (cases 1 and $2, H$ $=0.15 \mathrm{~m}, T=2 \mathrm{~s}, \mathrm{GWT}=5.5 \mathrm{~m})$ and higher $($ cases 3 and $4, H=0.15 \mathrm{~m}, T=2 \mathrm{~s}, \mathrm{GWT}=$ $8.5 \mathrm{~m})$ watertable levels. Upper panel: coarse sand. Lower panel: fine sand. Positive values represent exfiltration, while negative values show the infiltration. 
Fig. 8. Simulated phase-average in/exfiltration rates on the beach face for the higher watertable levels and different wave characteristics $(H=0.15 \mathrm{~m}, T=2 \mathrm{~s}$, cases 3 and 4; $H=0.25 \mathrm{~m}, T=2 \mathrm{~s}$, cases 7 and 8 ; and $H=0.15 \mathrm{~m}, T=4 \mathrm{~s}$, cases 11 and 12$)$. Upper panel: coarse sand. Lower panel: fine sand. Positive magnitudes represent exfiltration, while negative values show the infiltration.

Fig. 9. Simulated phase-average in/exfiltration rates on the beach face for the lower watertable levels and different wave characteristics $(H=0.15 \mathrm{~m}, T=2 \mathrm{~s}$, cases 1 and 2; $H=0.25 \mathrm{~m}, T=2 \mathrm{~s}$, cases 5 and 6; and $H=0.15 \mathrm{~m}, T=4 \mathrm{~s}$, cases 9 and 10). Upper panel: coarse sand. Lower panel: fine sand. Positive magnitudes represent exfiltration, while negative values show the infiltration.

Fig. 10. Numerical results for foreshore profile changes on the (a) coarse and (b) fine sand beaches for the lower (GWT $=5.5 \mathrm{~m})$, cases 1 and 2 , and higher $(\mathrm{GWT}=5.5 \mathrm{~m})$, cases 3 and 4, watertable level. For all panels $H=0.15 \mathrm{~m}, T=2 \mathrm{~s}$. Upper panel: coarse sand. Lower panel: fine sand.

Fig. 11. Numerical results for beach face profile changes on the coarse sand beach for the (a) lower inland watertable (cases 1, 5 and 9, for all cases: GWT = 5.5 m) and (b) higher inland watertable levels (cases $3(H=0.15 \mathrm{~m}, T=2 \mathrm{~s}), 7(H=0.25 \mathrm{~m}, T=2 \mathrm{~s})$ and 11 $(H=0.15 \mathrm{~m}, T=4 \mathrm{~s})$, for all cases: GWT $=8.5 \mathrm{~m})$.

Fig. 12. Numerical results for beach face profile changes on the fine sand beach for the (a) lower inland watertable (cases $2(H=0.15 \mathrm{~m}, T=2 \mathrm{~s}), 6(H=0.25 \mathrm{~m}, T=2 \mathrm{~s})$ and 10 $(H=0.15 \mathrm{~m}, T=4 \mathrm{~s})$, for all cases: GWT $=5.5 \mathrm{~m})$ and $(\mathrm{b})$ higher inland watertable levels (cases $4(H=0.15 \mathrm{~m}, T=2 \mathrm{~s}), 8(H=0.25 \mathrm{~m}, T=2 \mathrm{~s})$ and $12(H=0.15 \mathrm{~m}, T=4$ s), for all cases: GWT $=8.5 \mathrm{~m}$ ). 


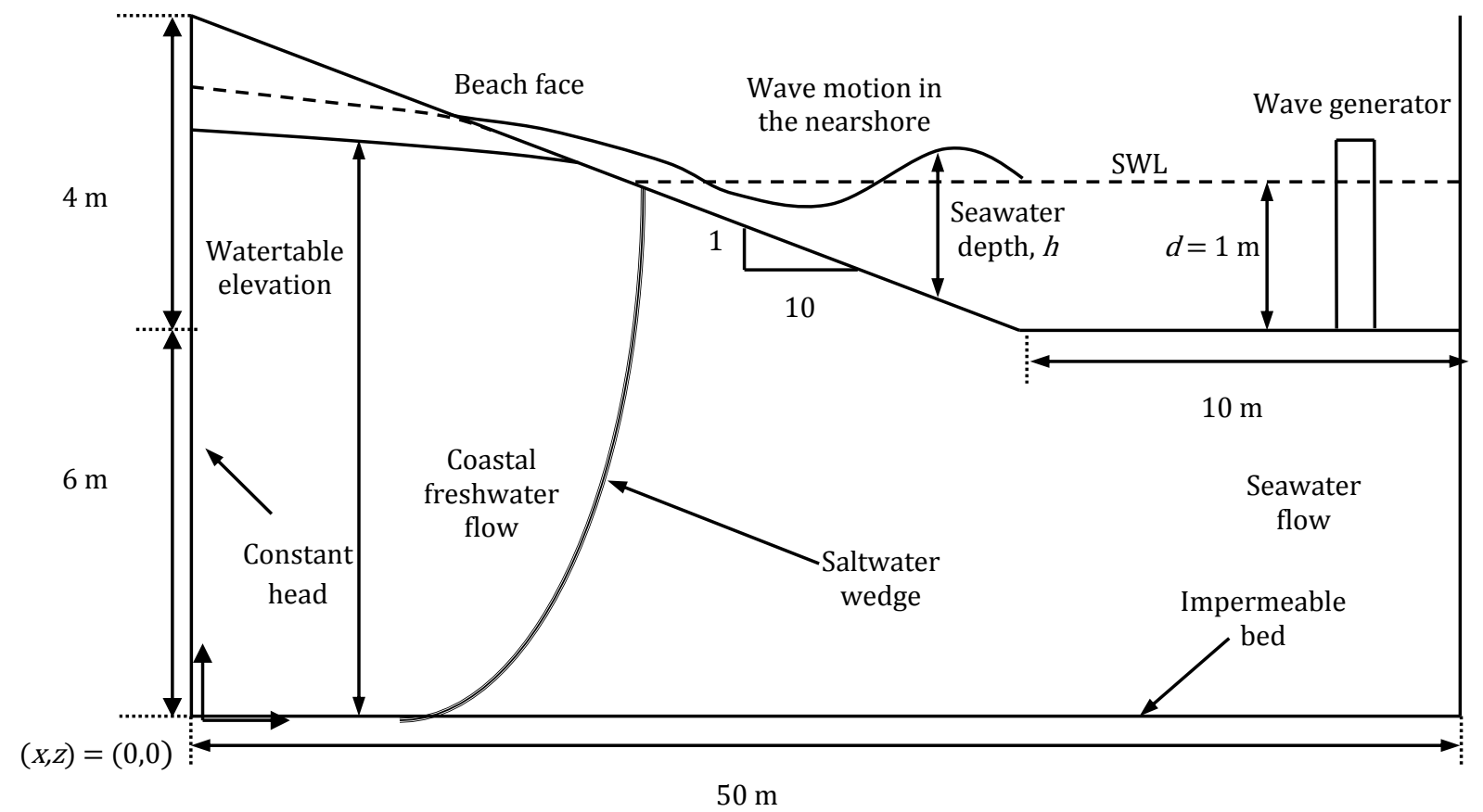

Fig.1 


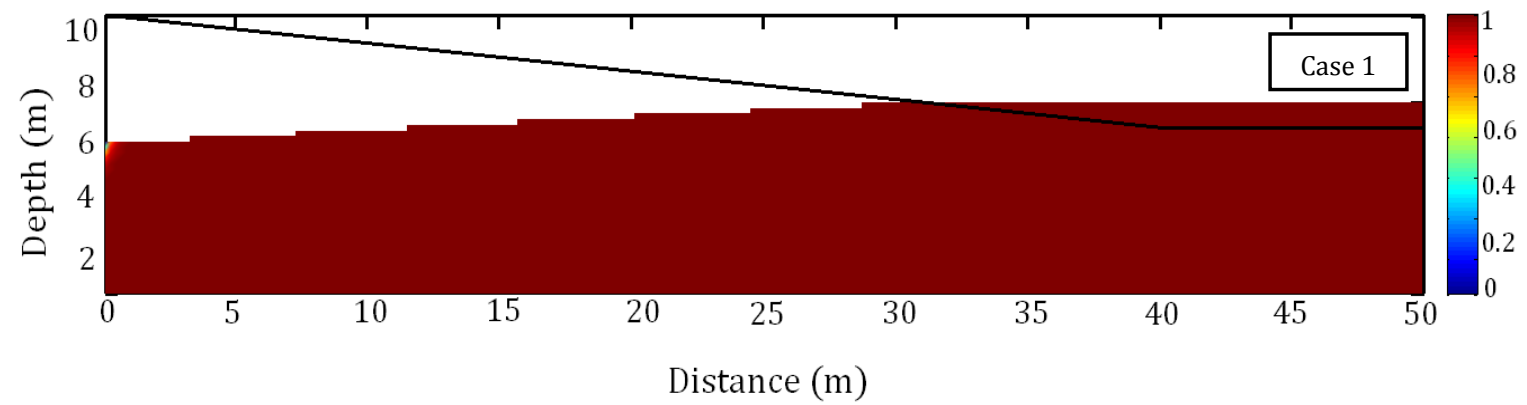

(a)

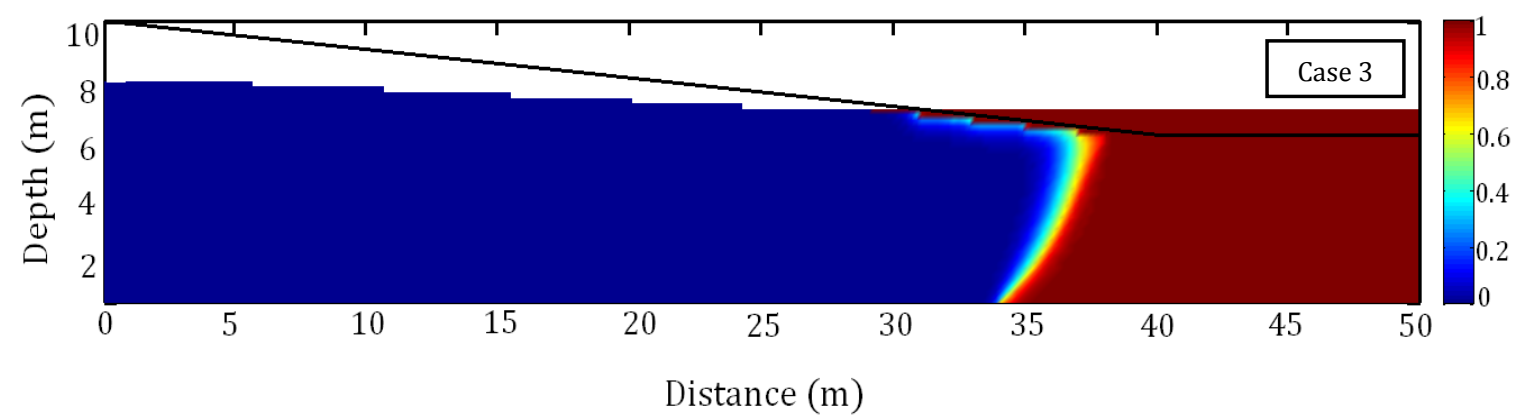

(b)

Fig. 2 


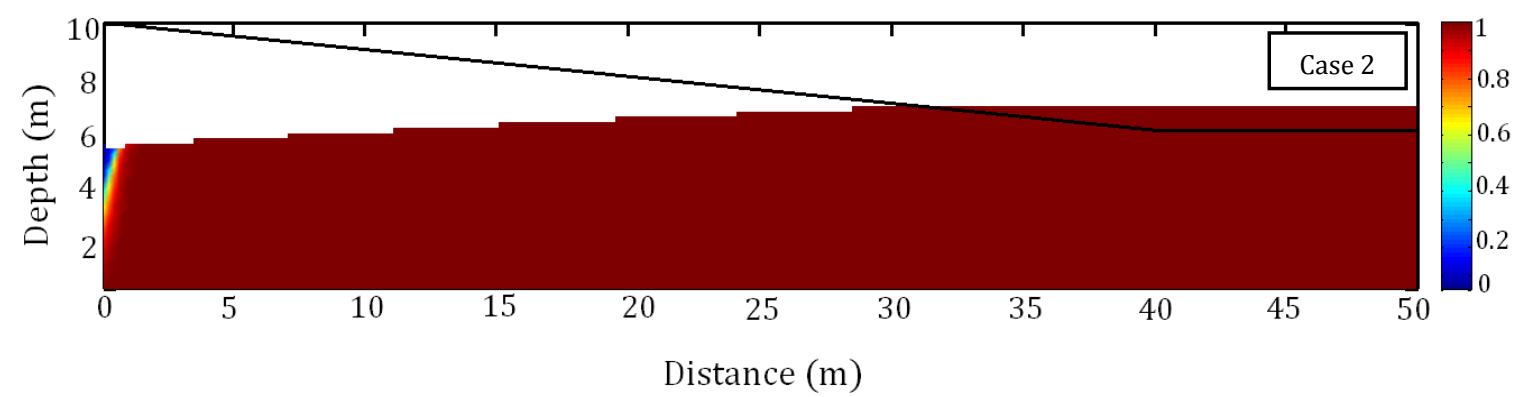

(a)

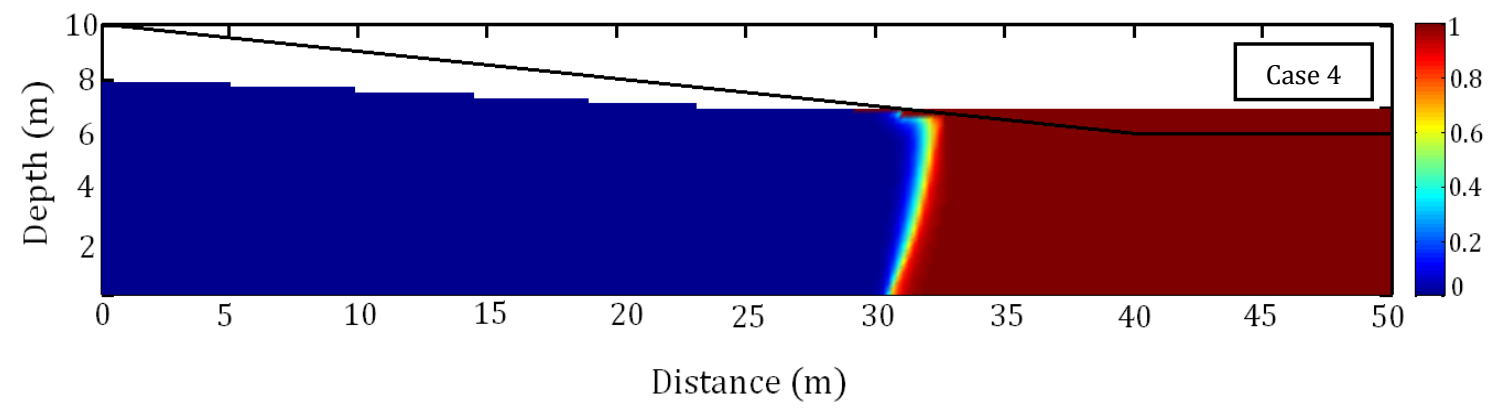

(b)

Fig.3 


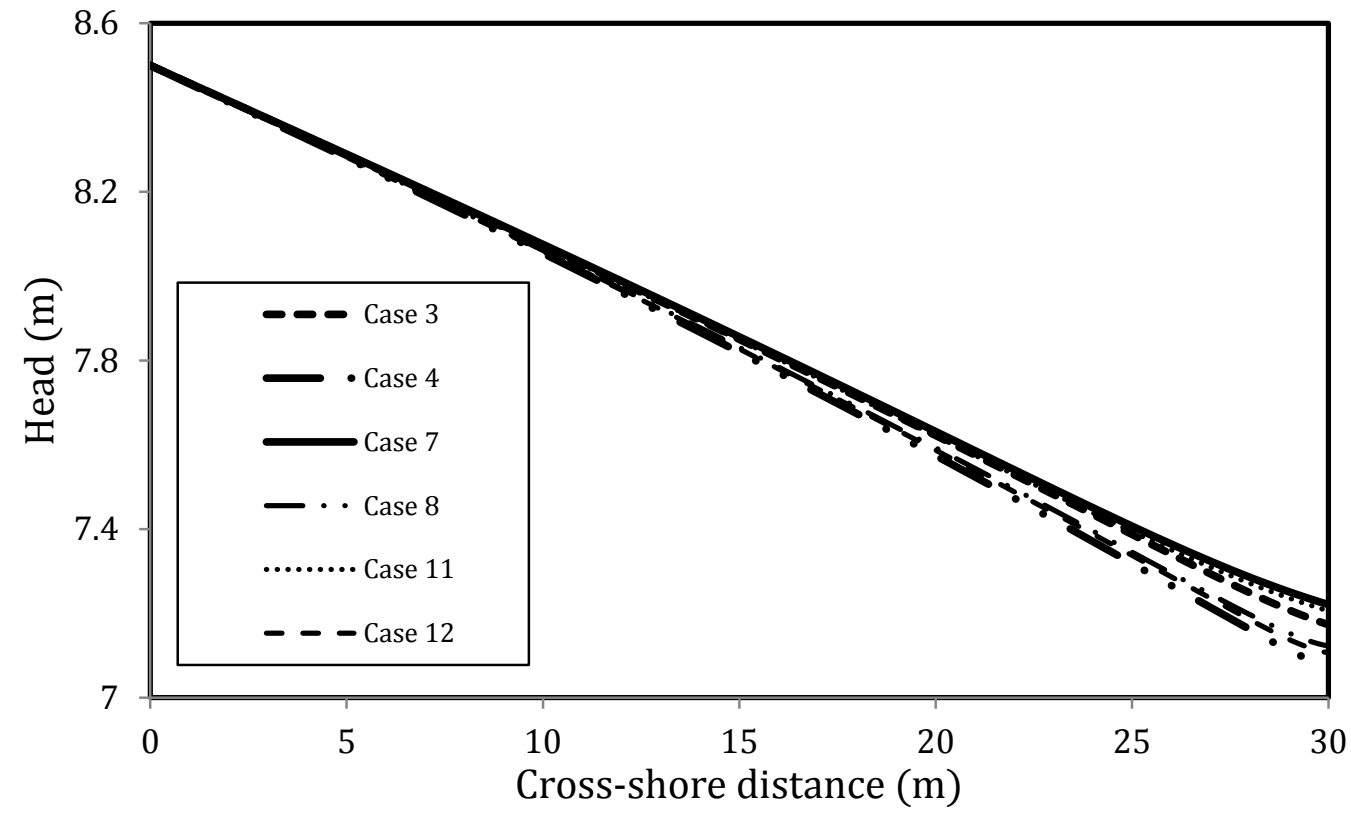

Fig.4 

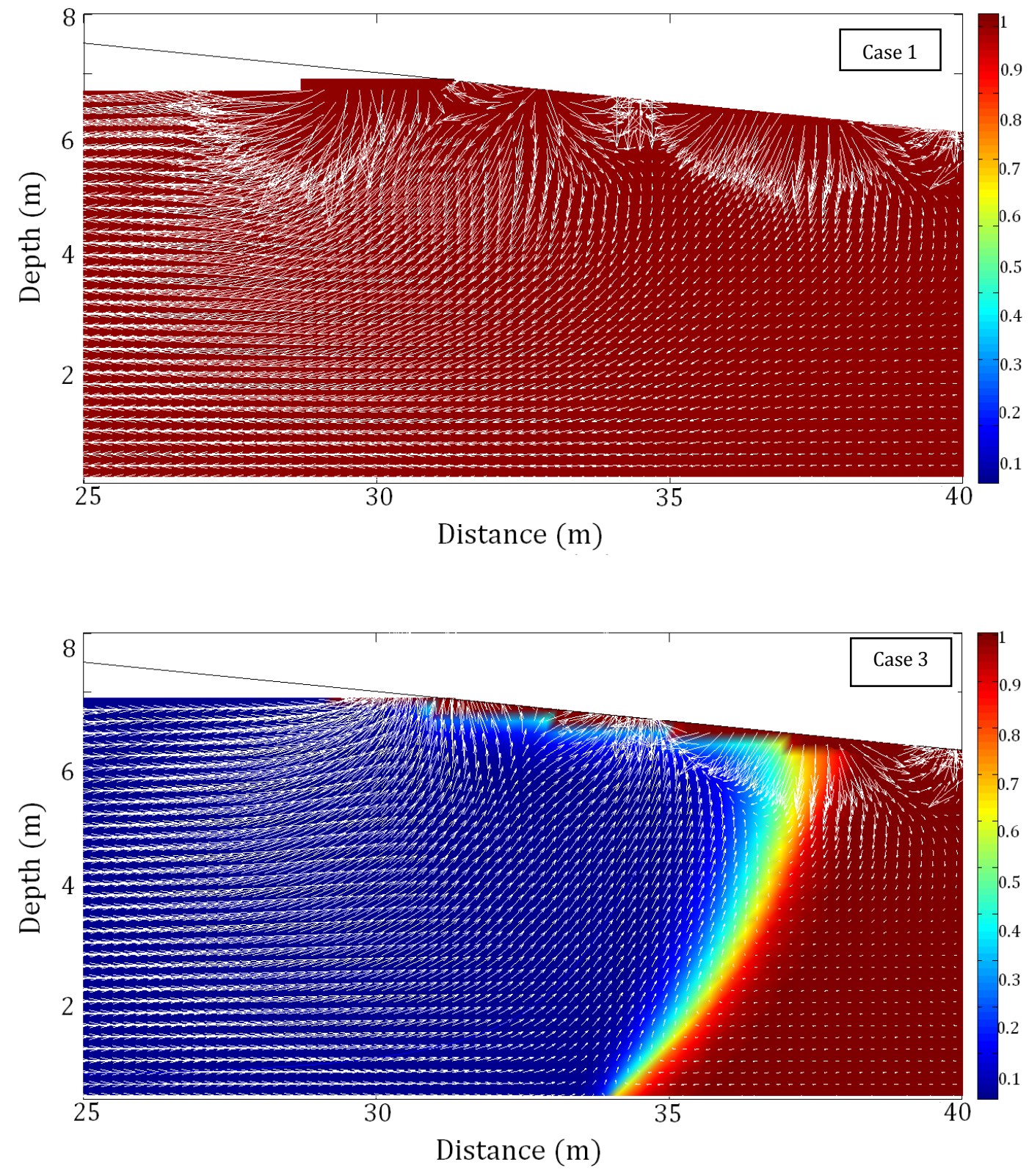

(a) 

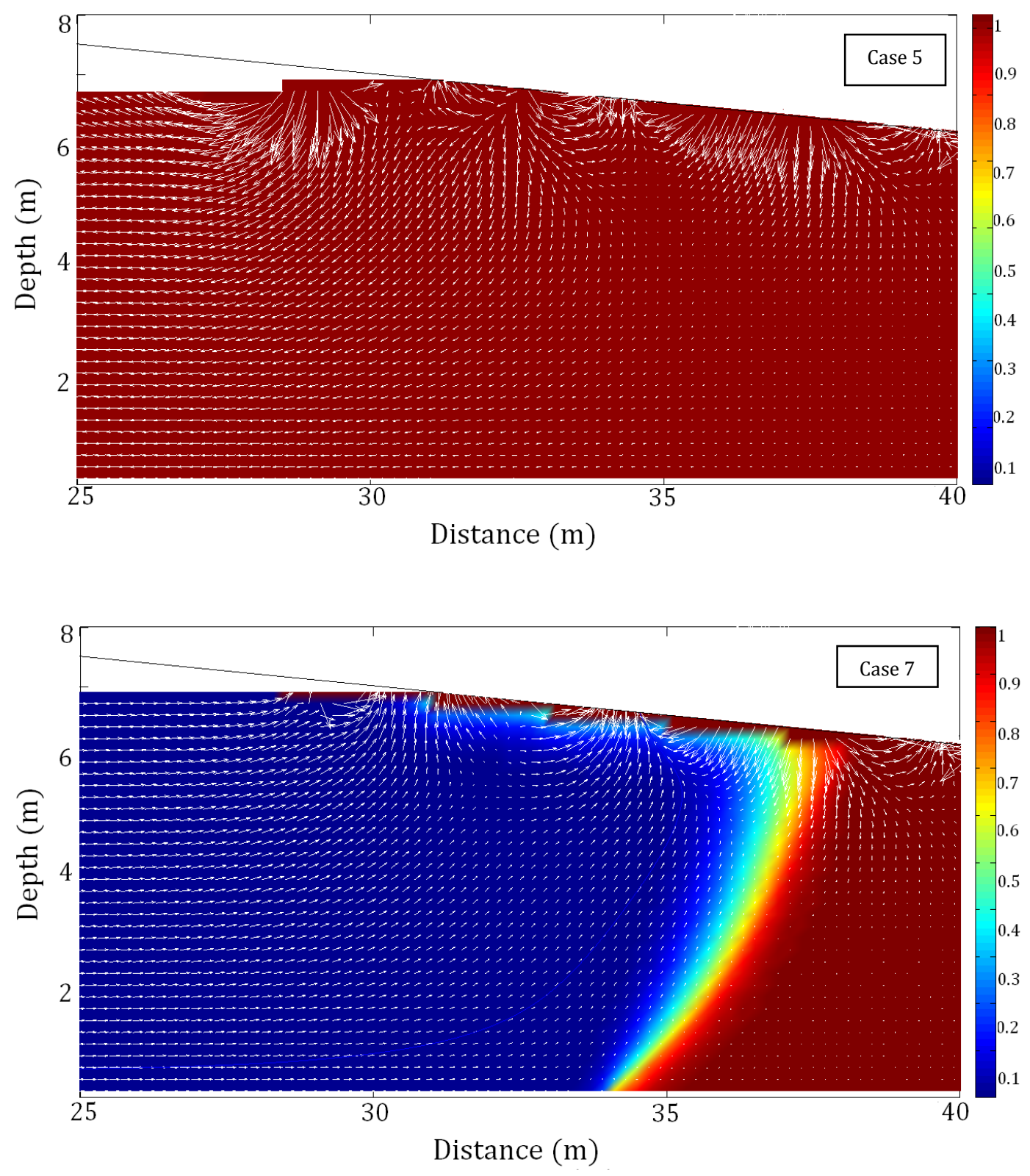

(b) 

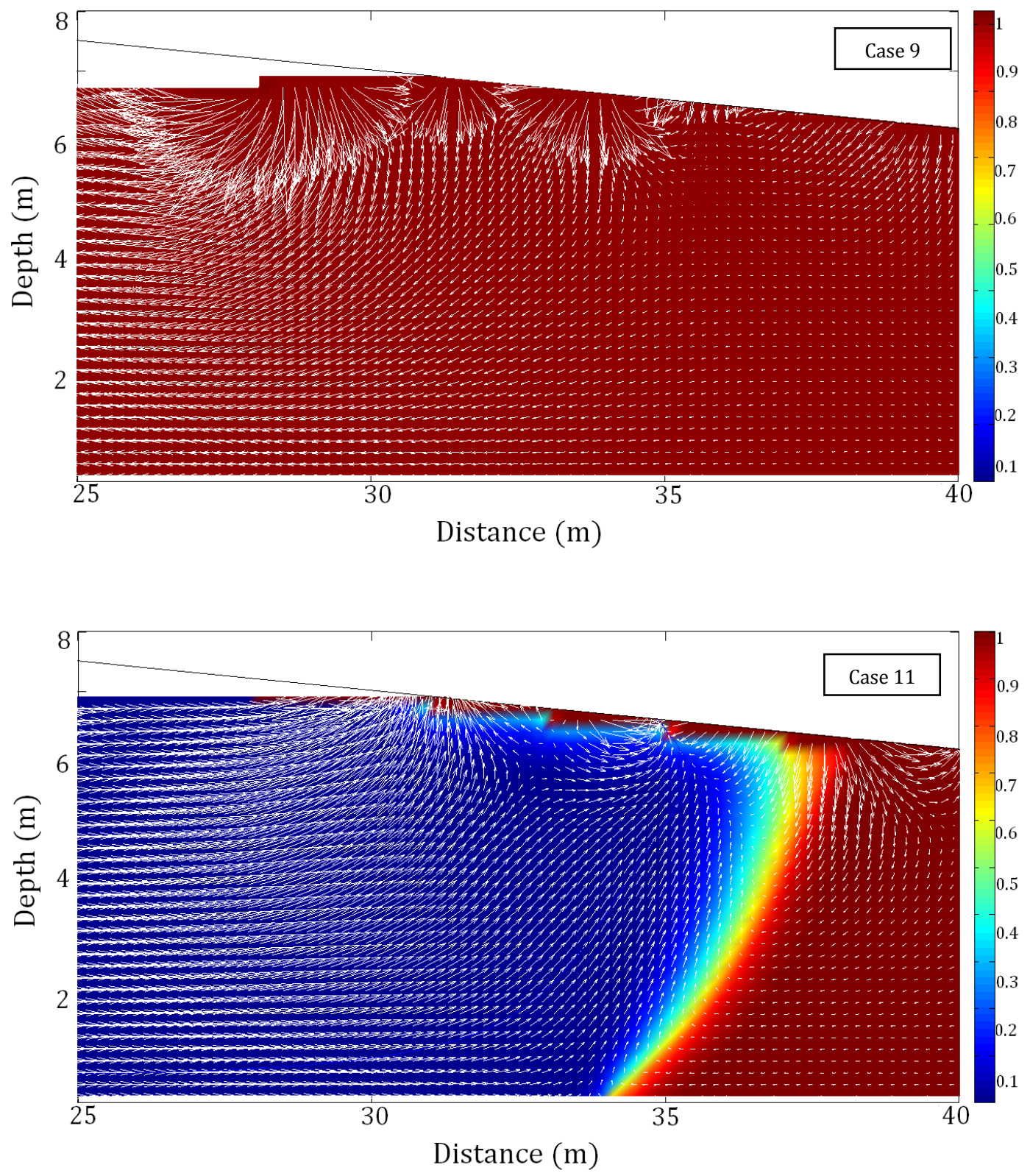

(c)

Fig. 5 

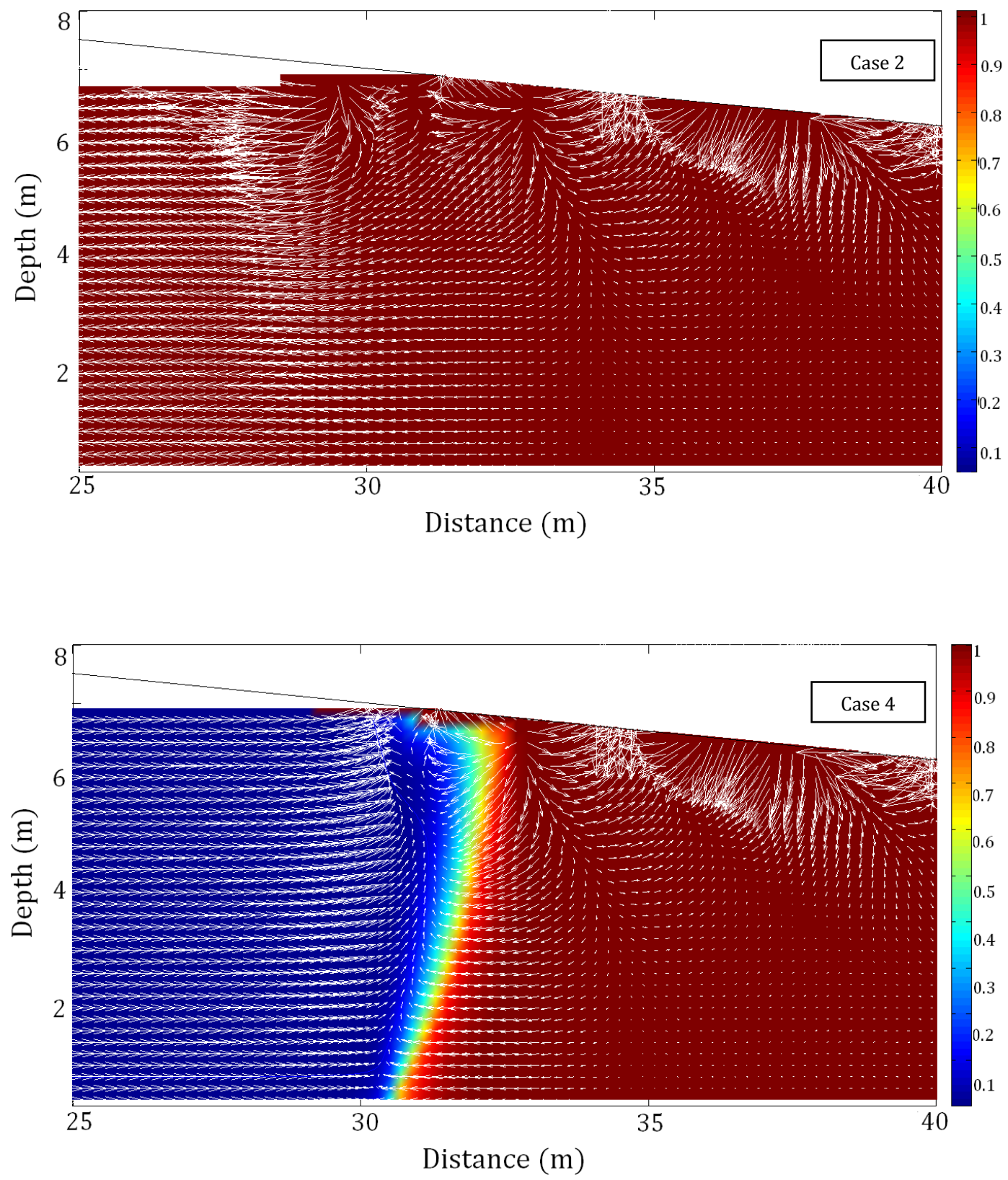

(a) 

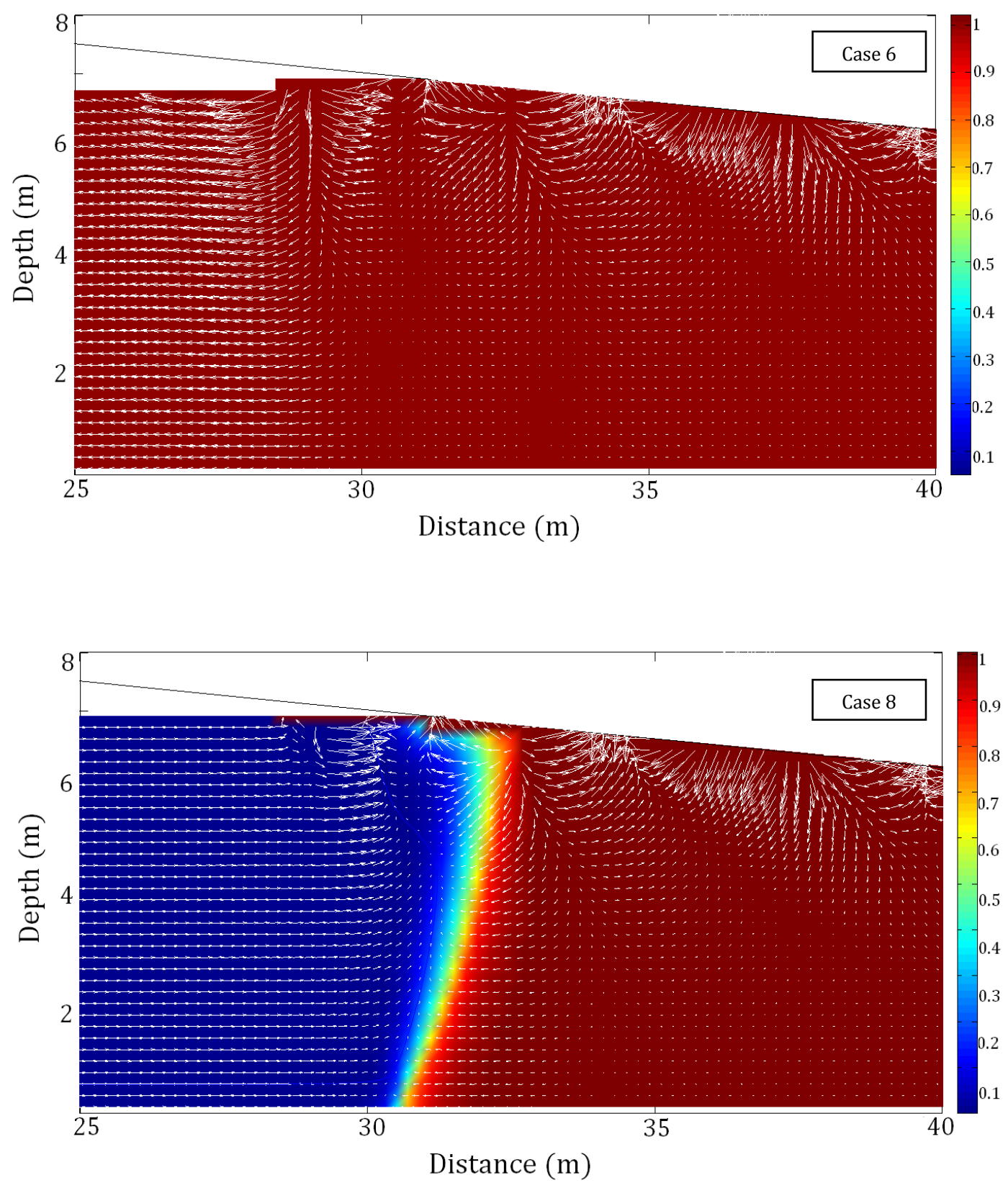

(b) 

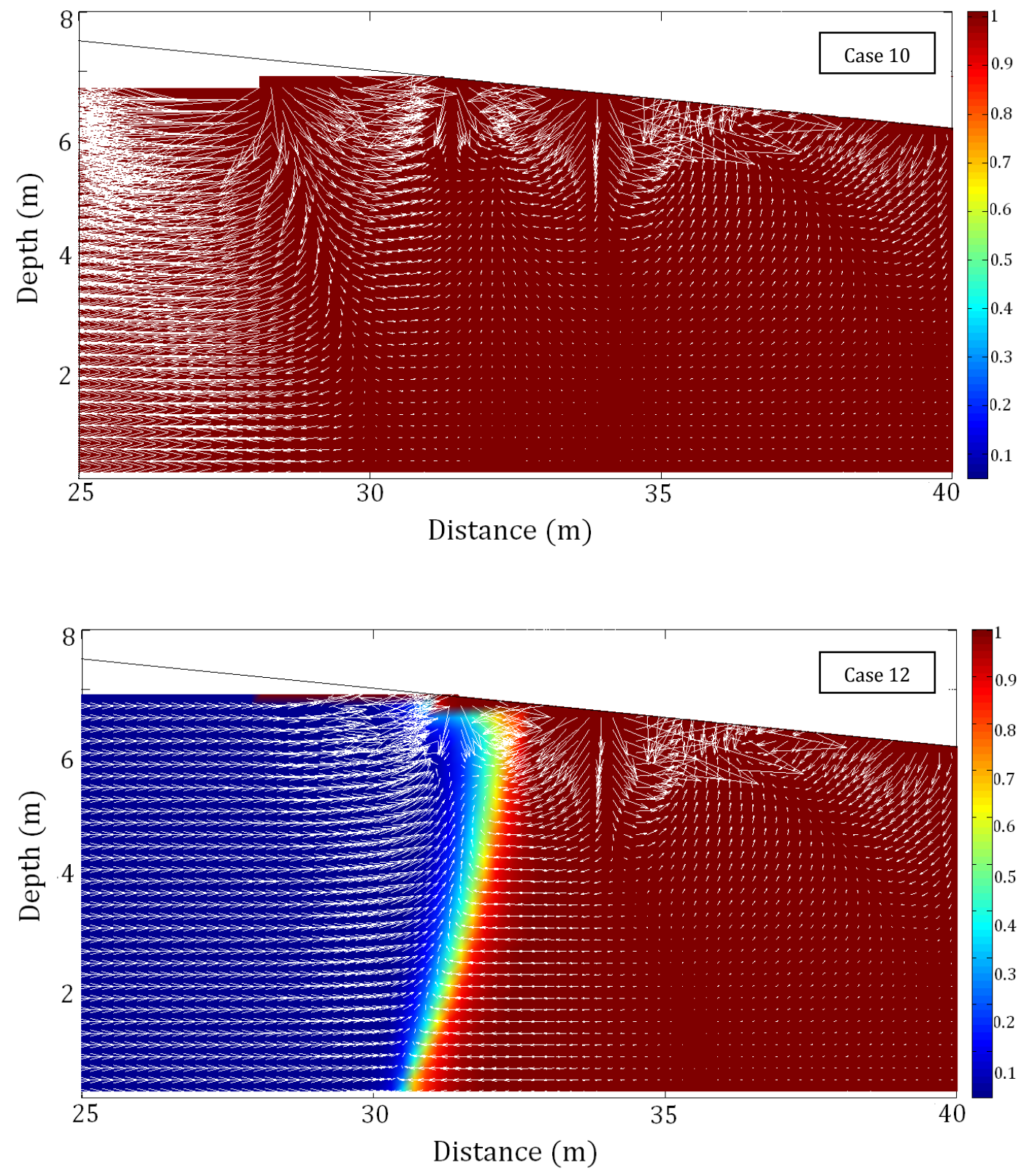

(c)

Fig. 6 


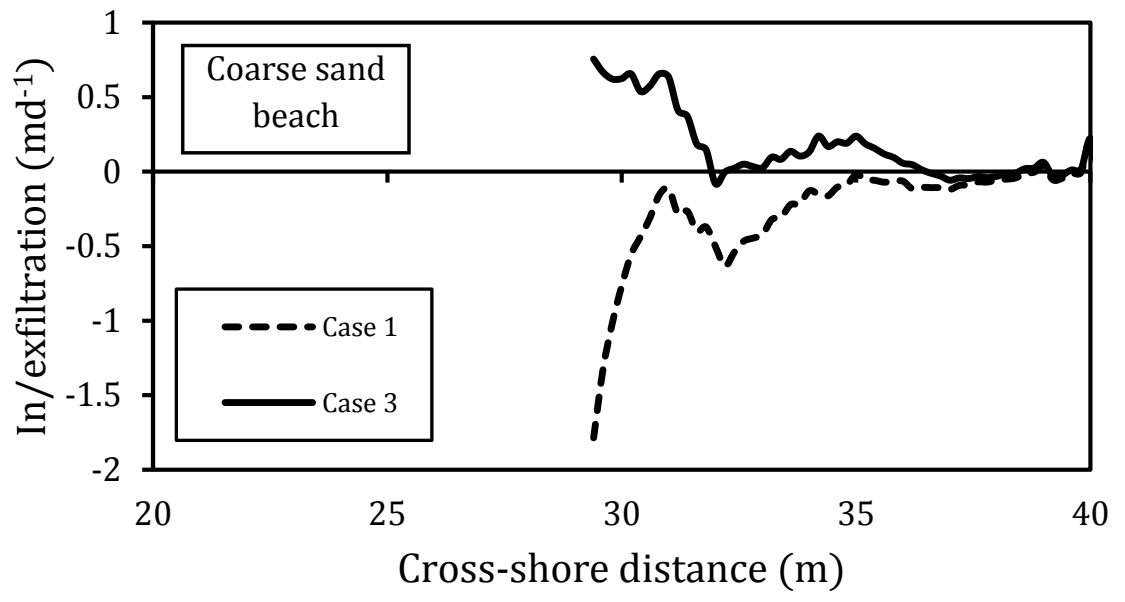

(a)

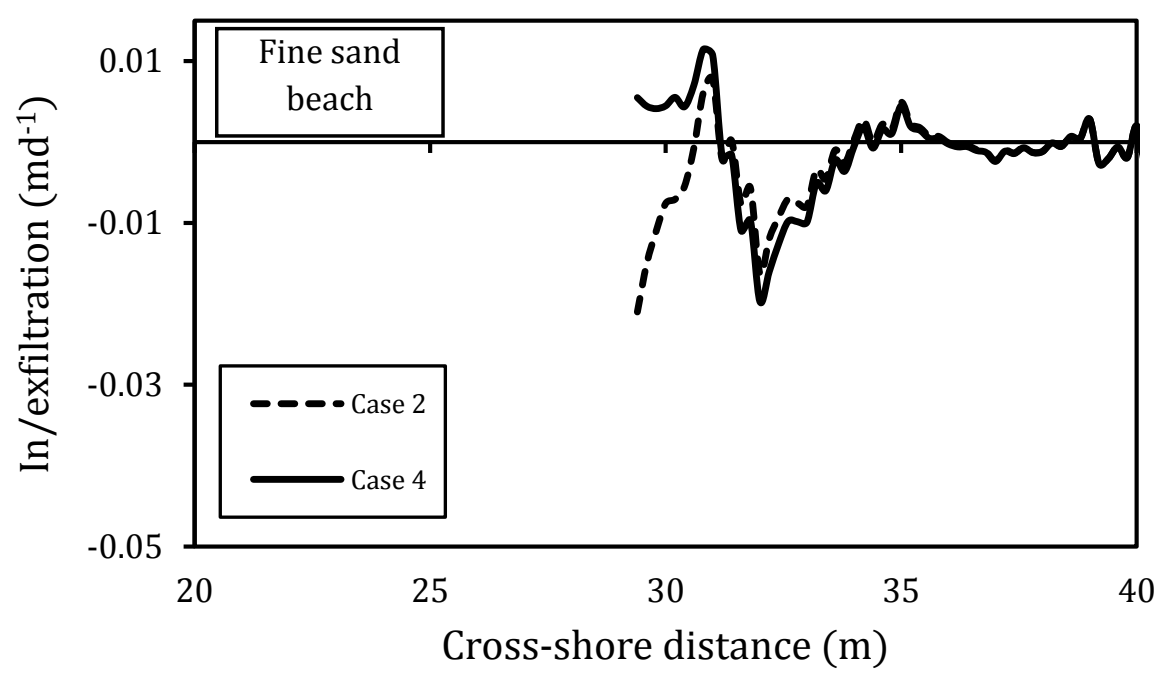

(b)

Fig. 7 


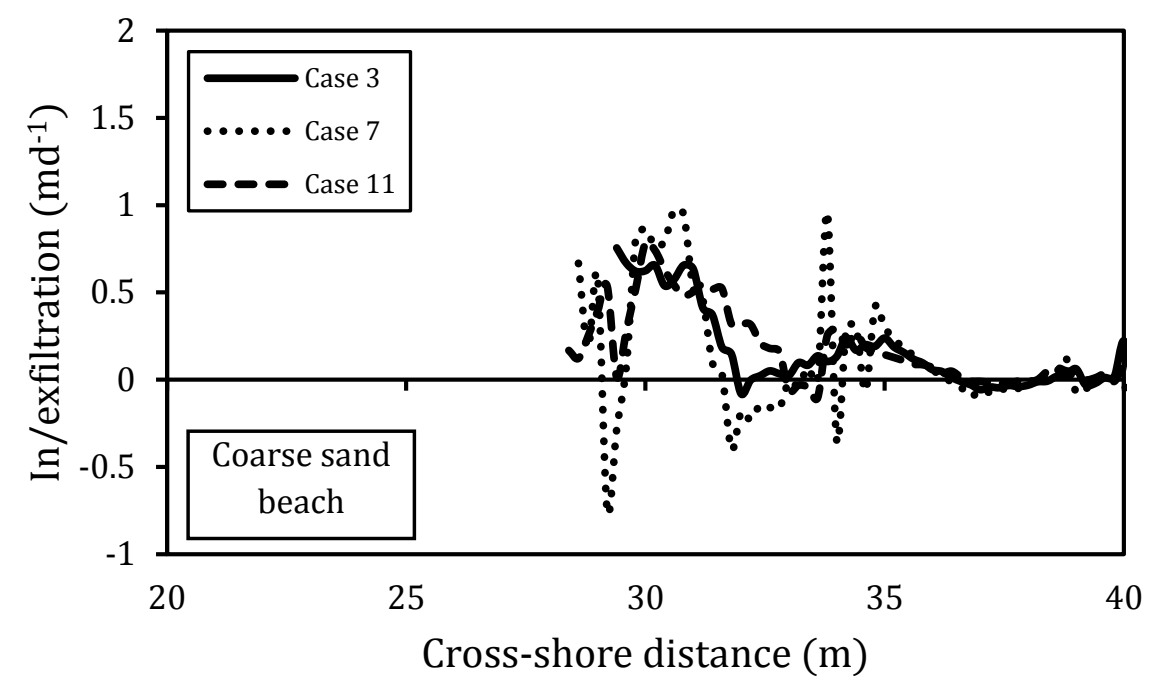

(a)

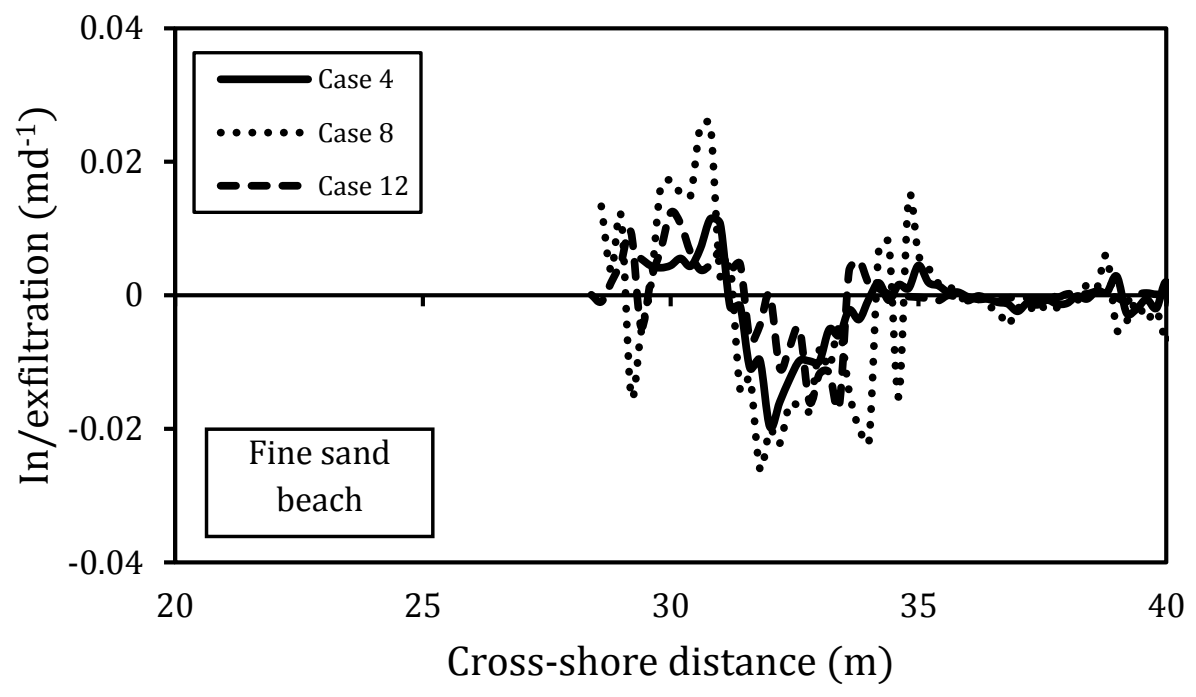

(b)

Fig.8 


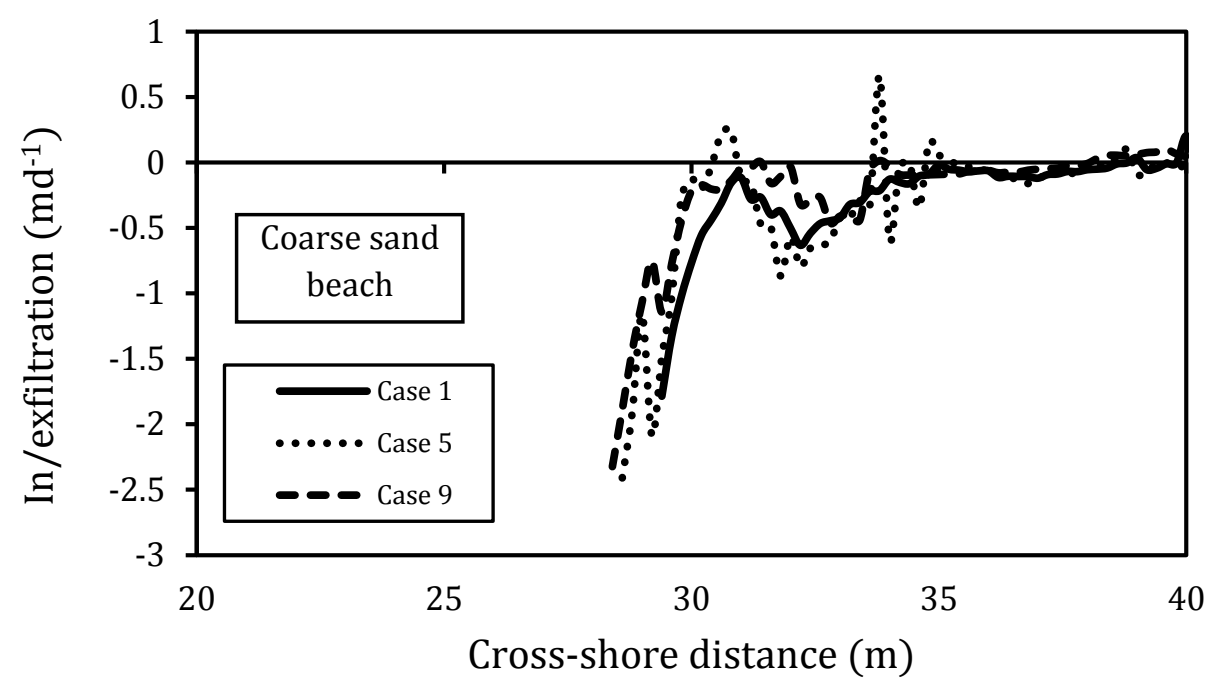

(a)

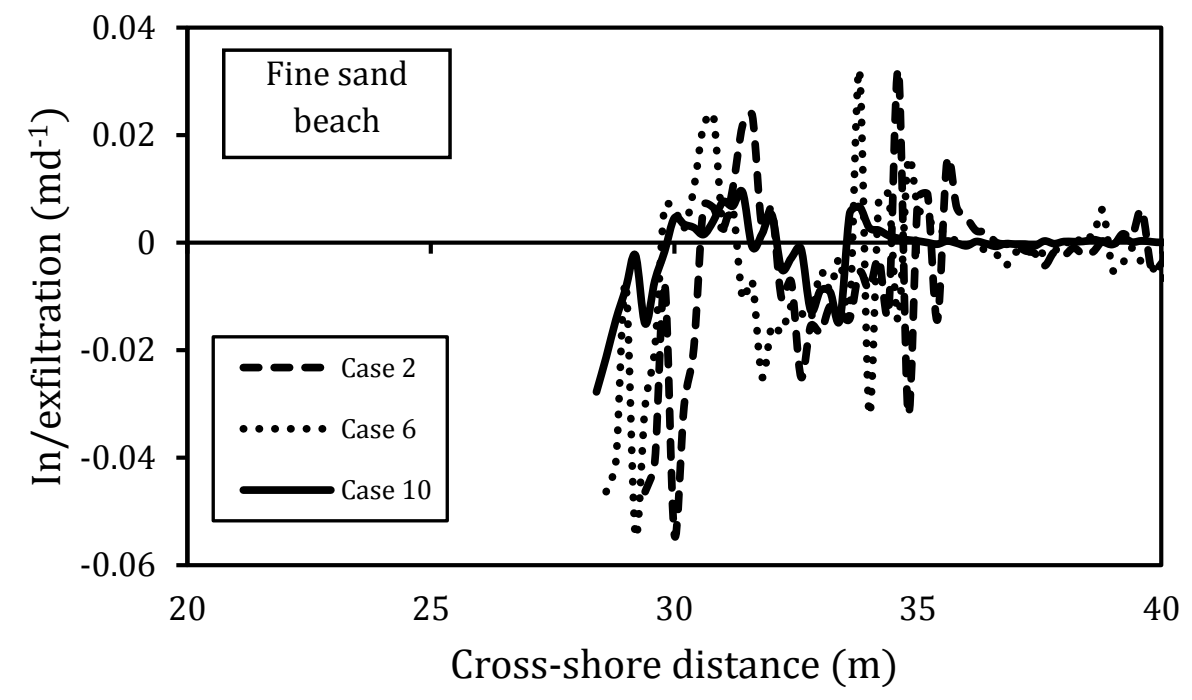

(b)

Fig. 9 


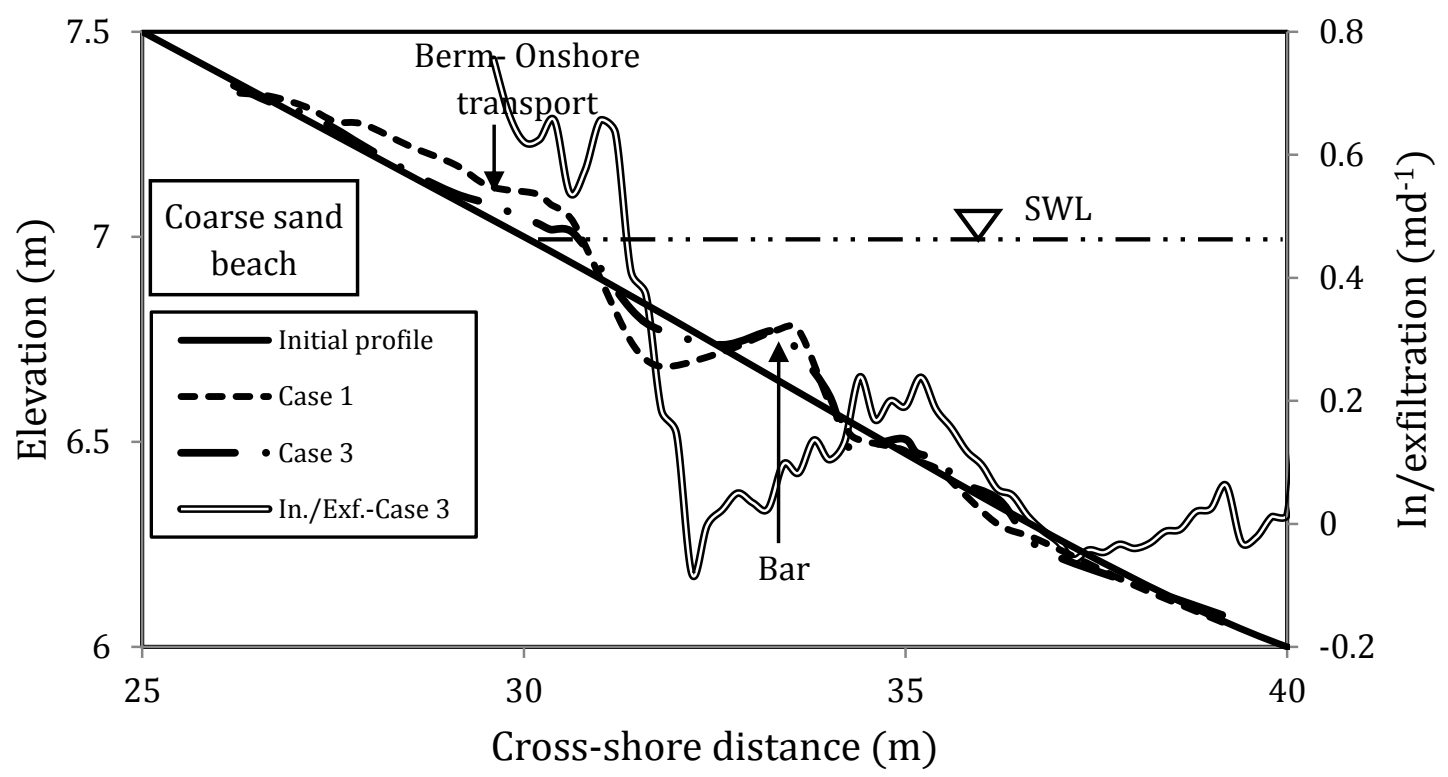

(a)

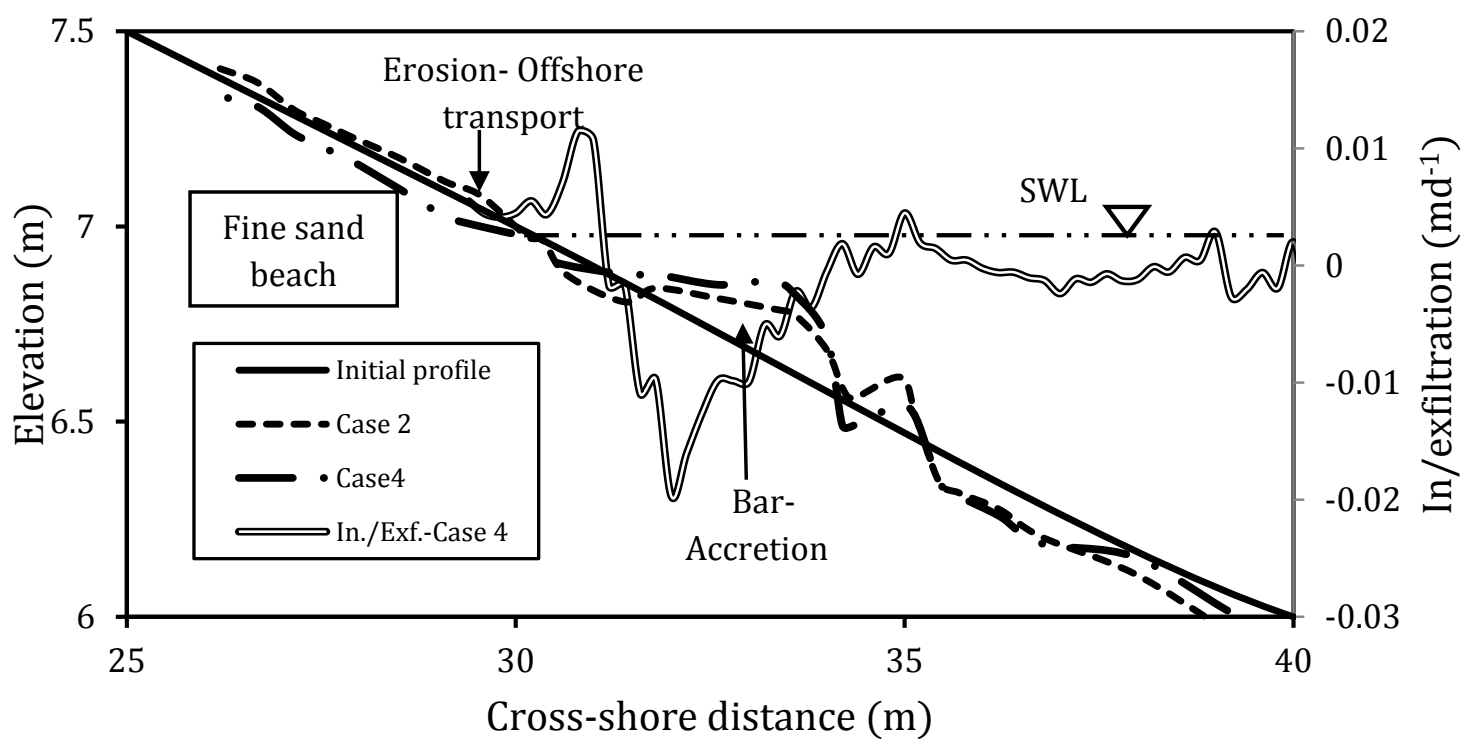

(b)

Fig.10 


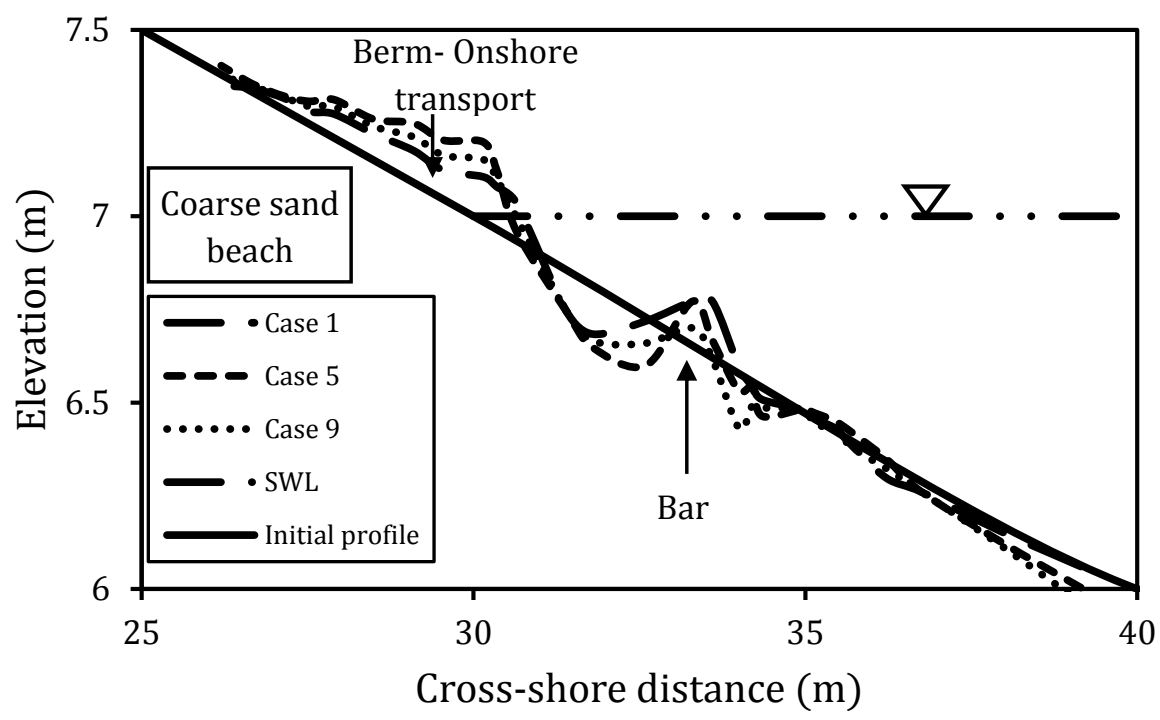

(a)

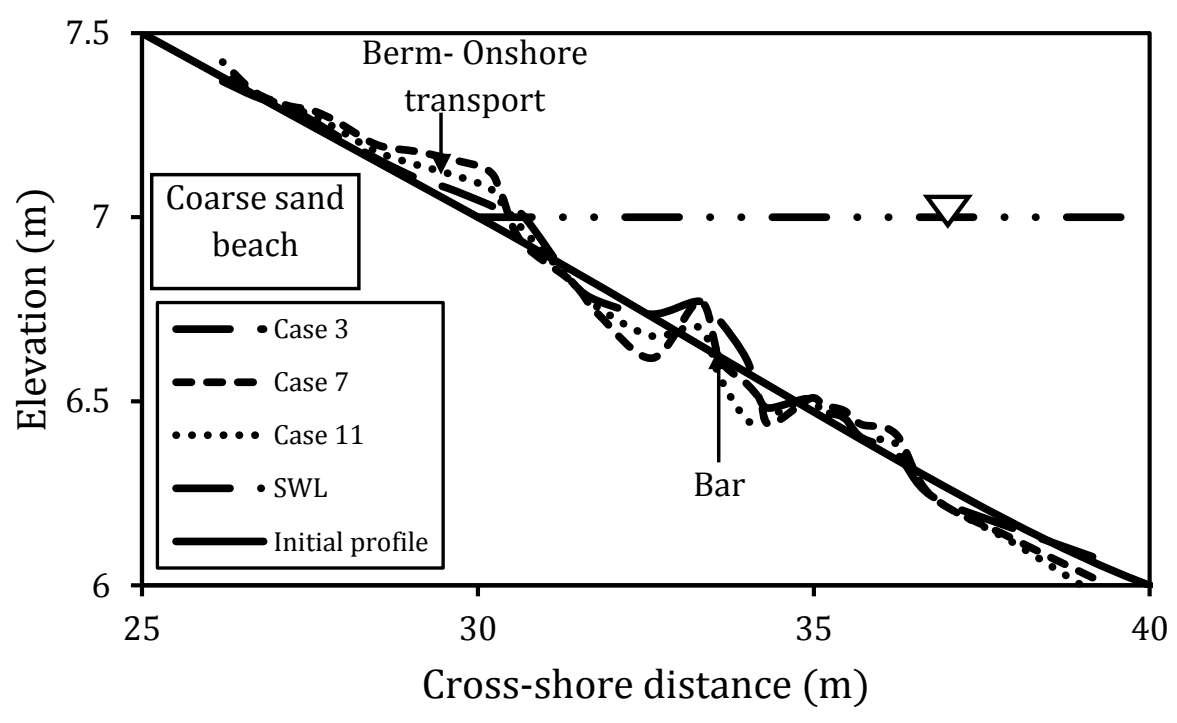

(b)

Fig.11 


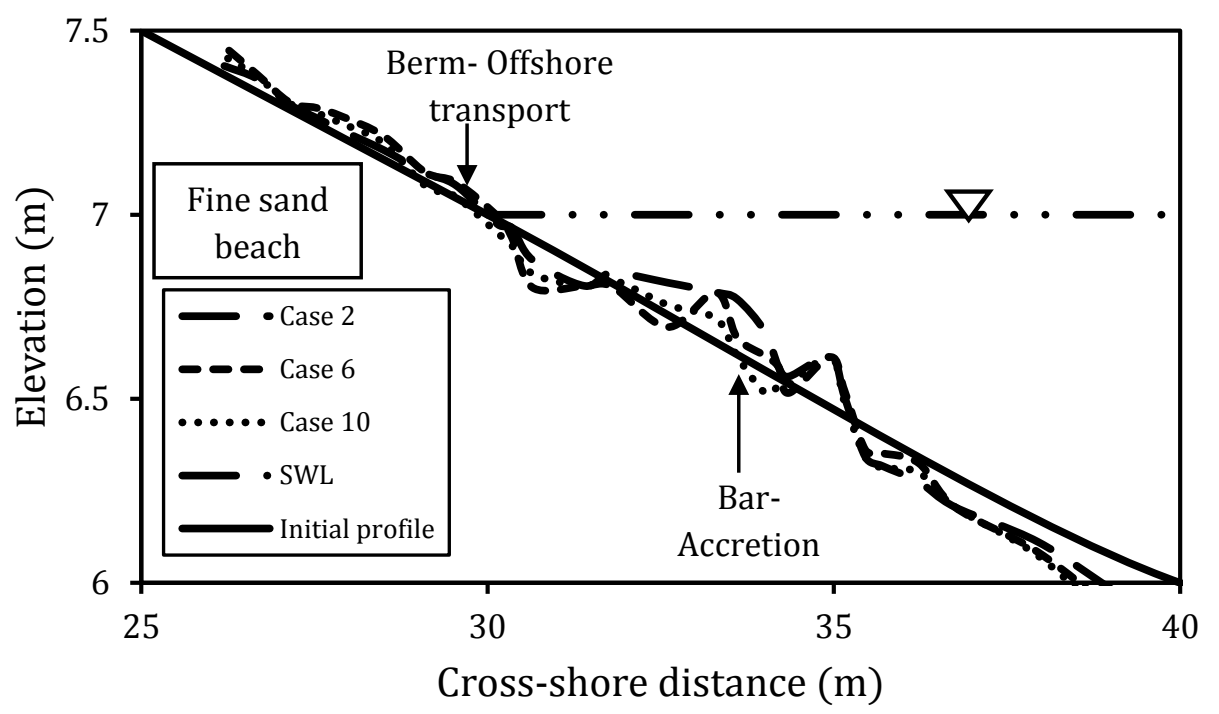

(a)

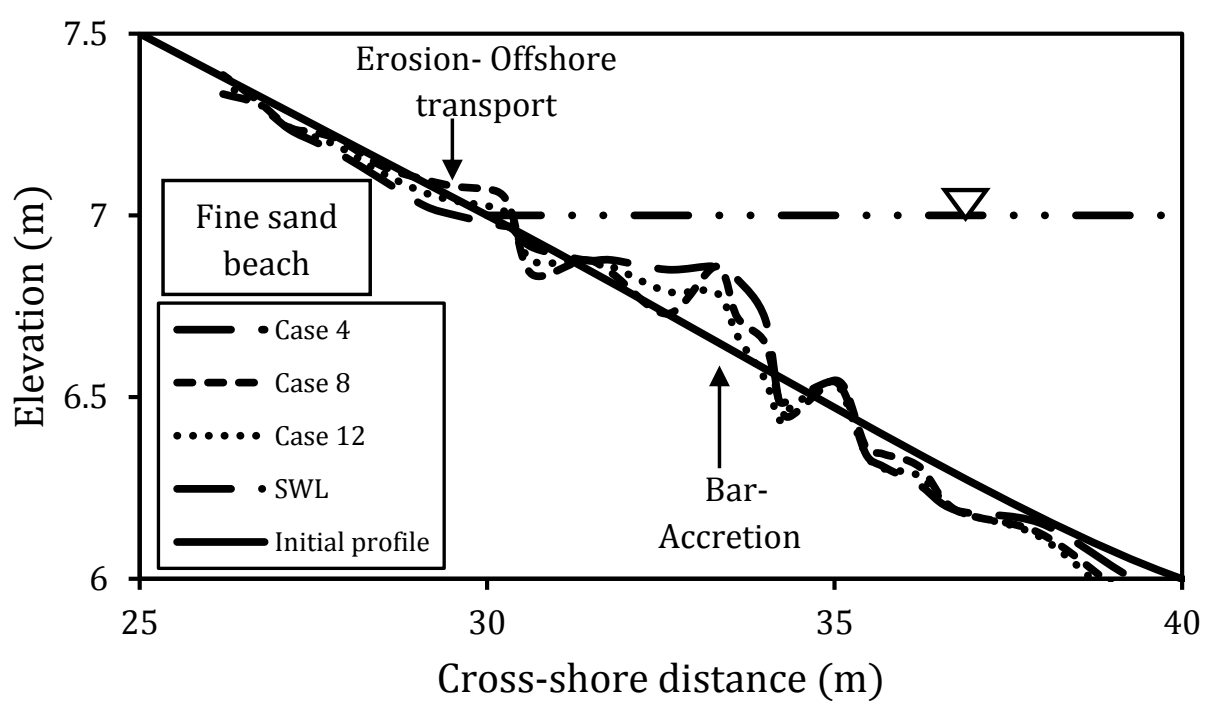

(b)

Fig.12 